Article

\title{
Optimal Vitamin D Supplementation Doses that Minimize the Risk for Both Low and High Serum 25- Hydroxyvitamin D Concentrations in the General Population
}

\author{
Paul J. Veugelers *, Truong-Minh Pham and John Paul Ekwaru \\ Received: 18 August 2015; Accepted: 27 November 2015; Published: 4 December 2015 \\ School of Public Health, University of Alberta, 350 University Terrace, Edmonton, AB T6G 2T4, Canada; \\ ptrminh@gmail.com (T.-M.P.); ekwaru@ualberta.ca (J.P.E.) \\ * Correspondence: paul.veugelers@ualberta.ca; Tel.: 1-780-492-9095
}

\begin{abstract}
The Recommended Dietary Allowance (RDA) is the nutrient intake considered to be sufficient to meet the requirements of $97.5 \%$ of the population. Recent reports revealed a statistical error in the calculation of the RDA for vitamin D opening the question of what the recommendation should be. We took a dual approach to answer this question: (1) we aggregated 108 published estimates on vitamin D supplementation and vitamin D status; and (2) we analyzed 13,987 observations of program participants. The aggregation of published data revealed that 2909 IU of vitamin D per day is needed to achieve serum 25-hydroxyvitamin D (25(OH)D) concentrations of $50 \mathrm{nmol} / \mathrm{L}$ or more in $97.5 \%$ of healthy individuals. For normal weight, overweight and obese program participants this was 3094, 4450 and $7248 \mathrm{IU}$ respectively. These supplementation doses would also result in $2.5 \%$ of normal weight, overweight and obese participants having 25(OH)D concentrations above 210, 200 and $214 \mathrm{nmol} / \mathrm{L}$ respectively. As these concentrations are high, an approach that minimizes the risk for both low and high concentrations seems desirable. With this approach we estimated, for example, that doses of 1885, 2802 and 6235 IU per day are required for normal weight, overweight and obese individuals respectively to achieve natural 25(OH)D concentrations (defined as 58 to 171 $\mathrm{nmol} / \mathrm{L}$ ). In conclusion, the large extent of variability in $25(\mathrm{OH}) \mathrm{D}$ concentrations makes a RDA for vitamin D neither desirable nor feasible. We therefore propose recommendations be articulated in the form of an optimal intake that minimizes the risk for both low and high serum $25(\mathrm{OH}) \mathrm{D}$ concentrations. This contribution includes body weight specific recommendations for optimal intakes for various combinations of lower and upper $25(\mathrm{OH}) \mathrm{D}$ concentration targets.
\end{abstract}

Keywords: vitamin D; vitamin D deficiency; recommended daily allowance; vitamin D supplementation; disease prevention; public health; nutrition; optimal vitamin D intake; optimal vitamin D status

\section{Introduction}

To ensure adequate intake the Institute of Medicine (IOM) issues nutritional recommendations. The Recommended Dietary Allowance (RDA) is the nutrient intake considered to be sufficient to meet the requirements of $97.5 \%$ of healthy individuals [1]. The current RDA for vitamin D is $600 \mathrm{IU}$ per day for individuals 1 to 70 years of age and $800 \mathrm{IU}$ per day for those above the age of 70 years [1]. This RDA is assumed to achieve adequate serum 25-hydroxyvitamin D $(25(\mathrm{OH}) \mathrm{D})$ concentrations in $97.5 \%$ of healthy individuals. Serum 25-hydroxyvitamin D (25(OH)D) is the established marker for vitamin D status.

The RDA for vitamin D has caused some controversy in the past [2,3]. One concern relates to the fact that the RDA is based on aggregations of studies that included clinical subgroups with 
compromised vitamin D status whereas the RDA is issued for the general population. Another concern relates to the fact that the RDA is uniform across body weight groups, whereas several studies have suggested that recommendations for supplementation should be body weight specific whereby obese individuals may need 2 to 3 times higher doses than normal weight subjects [4-7]. Further, some recent studies revealed the concern that despite compliance with recommended supplementation doses, serum $25(\mathrm{OH}) \mathrm{D}$ targets were still not met and vitamin D deficiency remained prevalent $[8,9]$. Most recently, reports from Canada and the US reported and confirmed a statistical error in the estimation of the RDA for vitamin D [10,11]. As it appears, the variability in serum $25(\mathrm{OH}) \mathrm{D}$ concentrations in response to vitamin D intake is much larger than was assumed $[10,11]$. This gives rise to the concern that recommendations may leave some subjects vitamin D deficient whereas others following the same recommendations may in fact respond with undesirable high serum $25(\mathrm{OH}) \mathrm{D}$ concentrations.

The objective of the present study is to characterize the optimal vitamin D supplementation needed to achieve $25(\mathrm{OH}) \mathrm{D}$ targets for the general population. In other words, how much vitamin $\mathrm{D}$ should we supplement to maximize adequate serum $25(\mathrm{OH}) \mathrm{D}$ concentrations while ensuring these concentrations are not getting too high. This study is not about advising on supplementation to achieve specific health benefits nor about revealing biological mechanisms.

\section{Methods}

We used two approaches to characterize the vitamin D supplementation needed to achieve 25(OH)D targets for the general population: (1) We searched the literature for studies reporting dose response relationships between vitamin $\mathrm{D}$ supplementation and serum $25(\mathrm{OH}) \mathrm{D}$ concentrations and extracted the reported means and standard deviations $(\mathrm{SD})$ of the serum $25(\mathrm{OH}) \mathrm{D}$ response. We included studies for which the mean age of participants was between 1 and 70 years, and we excluded studies among pregnant women. Based on the extracted means and SD's, we estimated the dose response relationship and lower and upper limits of the prediction interval: the lower limit, the 2.5th percentiles, as mean $-1.96 \times \mathrm{SD}$, and the upper limit, the 97.5 th percentiles, as mean $+1.96 \times \mathrm{SD}$. For this purpose we fitted a mixed effects regression model for the mean, the 2.5th and the 97.5th percentiles by vitamin D supplementation doses, weighting by the inverse of the squared standard errors of the respective mean responses. We applied a model with both an exponential and a linear term for the dose response relationship as this model provided the best fit [12]. We stratified these analyses to those with and without potentially compromised vitamin D status (e.g., were selected vitamin D deficiency cases, institutionalized, or hospitalized for long periods). We further stratified by latitude, type of vitamin D (D2 or ergocalciferol versus D3 or cholecalciferol), and duration of supplementation to illustrate their importance for the dose response relationship between vitamin $\mathrm{D}$ intake and serum 25(OH)D concentrations; (2) For our second approach we accessed and analyzed recordings of $25(\mathrm{OH}) \mathrm{D}$ concentrations from 18 to 70 years old healthy volunteer participants of a preventive health program provided by the Canada based Pure North $\mathrm{S}^{\prime}$ Energy Foundation (PN), a not-for-profit charitable organization providing free services since October 2007. The program employs health professionals who provide informed lifestyle counseling [13,14]. At enrollment, participants complete a lifestyle questionnaire, have a medical history and biometric measurements taken (height, weight, waist circumference, blood pressure) and have blood drawn for the assessment of serum $25(\mathrm{OH}) \mathrm{D}$. The collected information serves the purpose of informing the health professionals as a basis for the lifestyle counseling. This counseling includes customized recommendations on diet, physical activity, sleep and stress management. Dietary supplementation is often encouraged and vitamin D supplementation in particular given Canada's Northern latitude, limited sunlight and limited cutaneous synthesis of vitamin D. Follow up visits for health assessments and lifestyle counseling are scheduled annually. At baseline and each follow up visit health professionals interview the participants and record the amount of vitamin D supplementation participants have been taken. The primary objective of the PN program is lifestyle counseling and disease prevention rather than scientific research. However, the PN does make their collected data available, in anonymized form, to the University of Alberta to allow for secondary data analysis. For that purpose, 
participants signed and granted written informed consent to allow their relevant information to be used for secondary data analysis. More than $93 \%$ of participants in this program resided in latitudes above $50^{\circ} \mathrm{N}$ (median $=51.48^{\circ} \mathrm{N}$ ). Since inception of the PN program and till June 2013, serum 25(OH)D concentrations were assessed with an automated chemiluminescent immunoassay from DiaSorin (LIAISON) at the Calgary Laboratory Services (coefficient of variation (CV) of inter-assay was $11 \%$ ), and after this date with liquid chromatography-tandem mass spectrometry (LC-MS/MS) at Doctor's Data (CV of inter-assay was $2.4 \%$ and CV of intra-assay was $1.7 \%$ ). Both are accredited laboratories and both participate in proficiency surveys (DEQAS).

We excluded baseline records for which participants had indicated that they had taken vitamin D supplements rarely or for less than 3 months. This left us with a dataset of 11,693 participants with a total of 13,987 25(OH)D assessments and recordings of vitamin D supplementation. The supplementation ranged from 0 to $32,000 \mathrm{IU}$ per day. Though all supplementation values were considered in the statistical analyses, the figures depict only levels up to 20,000 IU because only 48 observations were in excess of 20,000 IU. We used quantile regression to model the effect of vitamin D supplementation on the 2.5 th percentile, the median and the $97.5 \%$ percentile of serum $25(\mathrm{OH}) \mathrm{D}$ concentrations. While traditional regression methods model the effects of the covariates on the mean of the dependent variable, quantile regression, which was introduced by Koenker and Bassett [15], extends this and allows modeling of the effects of covariates on different sections (percentiles) of the distribution of the dependent variable. We applied an exponential model as this model provided the best fit for these data and obtained confidence intervals (CI) for the estimates through bootstrapping with 500 replications. In addition, we used logistic regression to estimate the probability of having serum levels above a lower and below an upper serum $25(\mathrm{OH}) \mathrm{D}$ concentration. In this respect, we provide an example of having natural serum concentrations, defined as 58 to $171 \mathrm{nmol} 25(\mathrm{OH}) \mathrm{D} / \mathrm{L}$ [16]. We further provide these estimates for normal weight, overweight and obese participants. In these logistic regression models a log term of supplementation provided the best fit. To include zero supplementation levels, the $\log$ transformation requires an addition of a constant to supplementation levels. Instead of adding an arbitrary constant, we include this constant as an additional term in the model that was also estimated by the model fitting procedure.

PN anonymized their data prior to forwarding it to the University of Alberta for analyses. The Human Research Ethics Board of the University of Alberta approved access to and analysis of the PN data for the purpose of the present analyses. All analyses were conducted using SAS 9.4 (SAS Institute, Cary, NC, USA). Statistical significance was defined as a $p$-value of less than 0.05 .

\section{Results}

We retrieved a total of 36 published studies [17-52] that reported both the mean and standard deviations of serum 25(OH)D responses for a total of 108 study doses. The appendix lists these 36 studies and provides details on participants' characteristics, study size, supplementation dose, and mean and standard deviation of the serum $25(\mathrm{OH}) \mathrm{D}$ concentrations. The mean serum $25(\mathrm{OH}) \mathrm{D}$ concentrations reported in these studies ranged from 23 to $240 \mathrm{nmol} / \mathrm{L}$. The standard deviations ranged from 6.6 to 97.5 , had a mean value of 19.9 and a median value of $17.8 \mathrm{nmol} / \mathrm{L}$. Of the 108 study doses, 91 were reportedly given to healthy participants and 17 to participants with potentially compromised vitamin D status. When calculating the 2.5 th percentiles, three of the 108 study doses revealed negative values for serum $25(\mathrm{OH}) \mathrm{D}$ and were therefore excluded. Figure 1 presents the dose response relationship between vitamin D supplementation and serum $25(\mathrm{OH}) \mathrm{D}$ with the solid lines representing the fitted relationship for the mean and the dashed lines representing the fitted relationships for the 2.5th and 97.5th percentiles (the estimated 95\% prediction interval). The regression line started off lower for studies among participants with potentially compromised vitamin D status relative to studies among reportedly healthy participants, but for supplementation doses above $1000 \mathrm{IU}$ per day, the dose response relationship is similar for both groups (Figure 1). To achieve serum $25(\mathrm{OH}) \mathrm{D}$ concentrations of $50 \mathrm{nmol} / \mathrm{L}$ or more in $97.5 \%$ of reportedly healthy individuals, a dose of at least 2909 (95\% CI: 1962-10,847) IU per day is needed (Figure 1). At this supplementation dose (2909 IU per day) $2.5 \%$ of healthy individuals reach serum $25(\mathrm{OH}) \mathrm{D}$ concentrations in excess of 126 
nmol/L (Figure 1). Those with compromised vitamin D status need at least 3279 (1668-8740) IU per day to achieve serum $25(\mathrm{OH}) \mathrm{D}$ concentrations of $50 \mathrm{nmol} / \mathrm{L}$ or more in $97.5 \%$ of this subgroup. To achieve serum $25(\mathrm{OH}) \mathrm{D}$ concentrations of $40 \mathrm{nmol} / \mathrm{L}$ or more in $97.5 \%$ of reportedly healthy individuals, supplementation with at least 1229 (569-2819) IU per day is needed (Figure 1).

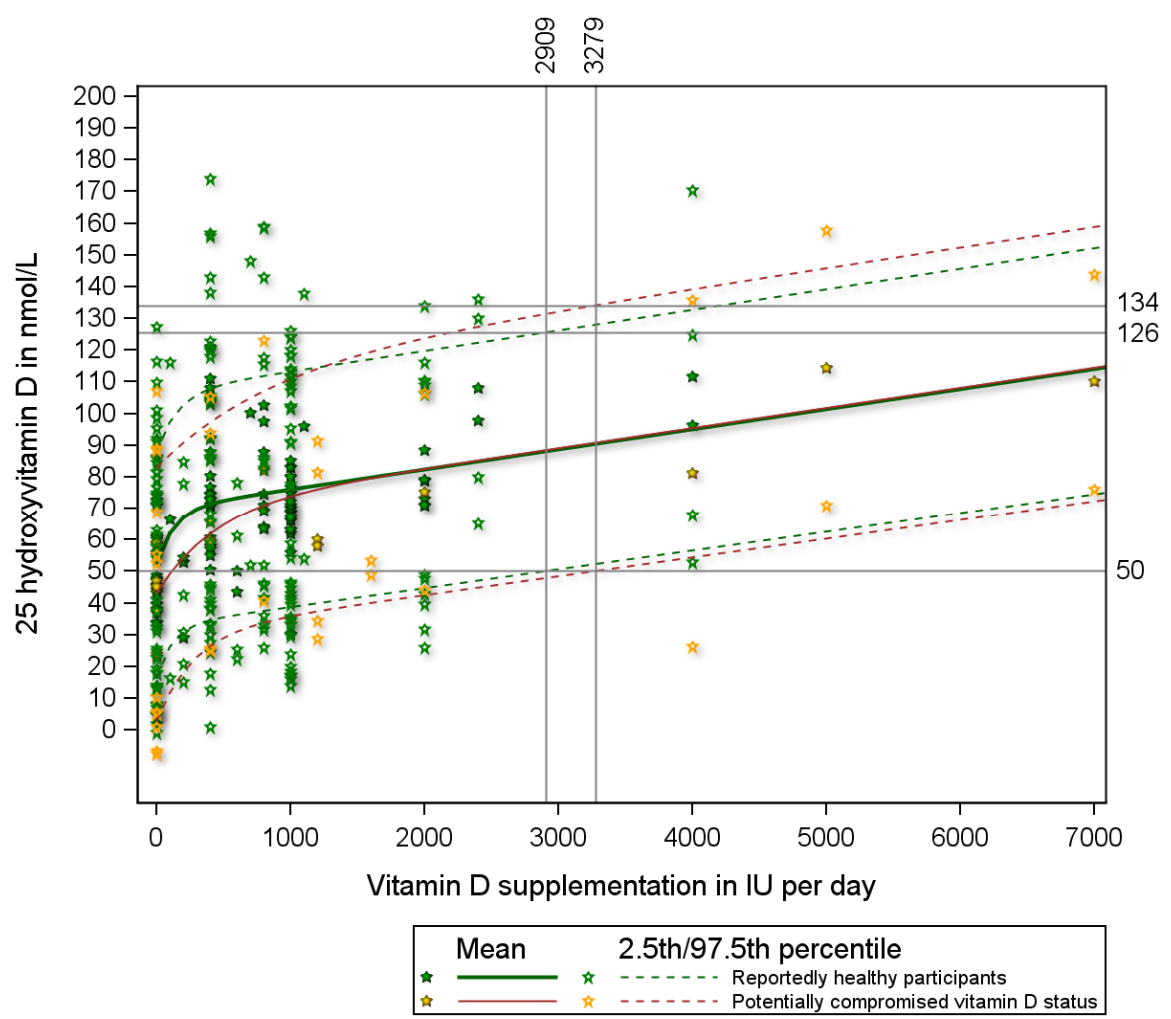

Figure 1. The mean and $95 \%$ prediction interval (2.5th and 97.5 th percentiles) of serum $25(\mathrm{OH}) \mathrm{D}$ concentrations by vitamin D supplementation derived from published study means and standard deviations. Note: The 2.5 percentile line depicts $25(\mathrm{OH}) \mathrm{D}$ concentrations for any given vitamin $\mathrm{D}$ supplementation dose with $2.5 \%$ of all expected $25(\mathrm{OH}) \mathrm{D}$ responses to have values below the line, and $97.5 \%$ to have values above the line. The 97.5 percentile line depicts $25(\mathrm{OH}) \mathrm{D}$ concentrations for any given vitamin D supplementation dose with $97.5 \%$ of all expected $25(\mathrm{OH}) \mathrm{D}$ responses to have values below the line, and $2.5 \%$ to have values above the line. The area between the 2.5 percentile line and the 97.5 percentile line depicts the $95 \%$ prediction interval of $25(\mathrm{OH}) \mathrm{D}$ concentrations for any given vitamin $\mathrm{D}$ supplementation dose. The equation for the mean response for reportedly healthy individuals is $Y=51.9+17.7^{*}\left(1-\mathrm{e}^{-7.4^{*} \mathrm{X}}\right)+6.3^{*} \mathrm{X}$ in which $\mathrm{Y}$ denotes serum $25(\mathrm{OH}) \mathrm{D}(\mathrm{in} \mathrm{nmol} / \mathrm{L})$ and $X$ vitamin D supplementation (in $1000 \mathrm{IUs}$ ).

The dose response relationship for reportedly healthy participants is further characterized by latitude, by type of vitamin D supplementation (vitamin D2 versus D3), and by the period between commencing supplementation and assessing serum $25(\mathrm{OH}) \mathrm{D}$ concentrations (supplementary figures $\mathrm{S} 1, \mathrm{~S} 2$ and S3 respectively). Relative to studies executed in regions between $50^{\circ} \mathrm{S}$ and $50^{\circ} \mathrm{N}$, participants of studies above $50^{\circ} \mathrm{N}$ had $25(\mathrm{OH}) \mathrm{D}$ concentrations that were on average approximately $10 \mathrm{nmol} / \mathrm{L}$ lower, and participants of studies below $50^{\circ} \mathrm{S}$ had concentrations that were approximately $20 \mathrm{nmol} / \mathrm{L}$ lower (Supplementary Figure S1). Supplementary Figure S2 depicts the dose response relationships for studies examining vitamin D3 supplementation exclusively and for the compilation of studies examining either vitamin D2, vitamin D3 or unspecified vitamin D types. Too few studies had examined vitamin D2 to allow for a direct comparison of vitamin D2 with vitamin D3. The fact that these dose response relationships are almost identical suggests the dose response relationships for vitamin D2 and vitamin D3 may be similar. Supplementary Figure S3 depicts the dose response relationships by period between commencing supplementation and assessing serum 25(OH)D concentrations. Also here, too few studies with a short period between commencing supplementation 
and assessment of serum $25(\mathrm{OH}) \mathrm{D}$ concentrations were available to allow for stratification by the length of this period. The difference between the dose response relationships depicted in supplementary Figure S3 suggests that too short a period between commencing supplementation and assessing serum $25(\mathrm{OH}) \mathrm{D}$ concentrations lead to an underestimation of serum $25(\mathrm{OH}) \mathrm{D}$ for any given supplementation dose.

Table 1 presents a summary of the 13,987 assessments of the 11,693 program participants. Of all the assessments, $33.2 \%, 1.4 \%, 36.7 \%$ and $28.8 \%$ were from normal weight, underweight, overweight and obese participants respectively (Table 1). Figure 2 depicts the 2.5th percentile, the median and 97.5th percentile of serum $25(\mathrm{OH}) \mathrm{D}$ concentrations in response to supplementation ranging from 0 to $20,000 \mathrm{IU}$ per day. The 2.5th percentile of $50 \mathrm{nmol} / \mathrm{L}$ is achieved with supplementation intake of 4469 (3607-6015) IU per day (Figure 2). At this supplementation levels, 2.5\% of participants reach serum $25(\mathrm{OH}) \mathrm{D}$ concentrations in excess of $210 \mathrm{nmol} / \mathrm{L}$. For normal weight, overweight and obese subgroups, supplementation with 3094 (2288-3658) IU, $4450(2977-13,976)$ IU and $7248(4770-10,797)$ $\mathrm{IU}$, respectively, are estimated to be required to achieve a 2.5 th percentile of $50 \mathrm{nmol} / \mathrm{L}$ respectively. At these supplementation intakes, $2.5 \%$ of the individuals would reach serum $25(\mathrm{OH}) \mathrm{D}$ levels in excess of $210 \mathrm{nmol} / \mathrm{L}, 200 \mathrm{nmol} / \mathrm{L}$, and $214 \mathrm{nmol} / \mathrm{L}$, repectively. Figure 2 further reveals that the 2.5 th percentile line does not exceed $60 \mathrm{nmol} / \mathrm{L}$ for the depicted supplementation range of 0 to 20,000 IU per day.

Table 1. Summary of 13,987 simultaneous assessments of reported vitamin D supplementation and serum $25(\mathrm{OH}) \mathrm{D}$ level from 11,693 participants.

\begin{tabular}{ccccc}
\hline & $N$ & $\%$ & Mean & Std \\
\hline Vitamin D supplementation (IU per day) & 13,987 & & 2484.6 & 3993.8 \\
Plasma 25(OH)D level nmol/L & 13,987 & & 88.9 & 47.6 \\
Age (Years) & & & & \\
$<40$ & 5270 & 37.7 & & \\
40 to 49 & 3123 & 22.3 & & \\
50 to 59 & 3528 & 25.2 & & \\
60+ & 2066 & 14.8 & & \\
Gender & & & & \\
Female & 6760 & 48.3 & \\
Male & 7227 & 51.7 & \\
Weight Status & & & \\
Normal weight & 4470 & 33.1 & & \\
Underweight & 184 & 1.4 & & \\
Overweight & 4943 & 36.7 & \\
Obesity & 3888 & 28.8 & \\
Season & & & \\
Winter & 4685 & 33.5 & \\
Spring & 4198 & 30.0 & \\
Summer & 2717 & 19.4 & \\
Fall & 2387 & 17.1 & \\
\hline
\end{tabular}

Luxwolda et al. [16] had revealed that natural 25(OH)D concentrations range from 58 to $171 \mathrm{nmol} / \mathrm{L}$. Figure 3 presents the proportion of individuals with serum $25(\mathrm{OH}) \mathrm{D}$ concentrations of $58 \mathrm{nmol} / \mathrm{L}$ or more by vitamin D supplementation level (the purple line) and the proportion of participants with concentrations of $171 \mathrm{nmol} / \mathrm{L}$ or less (the green line). Clearly, with increasing supplementation doses, the proportion of participants with serum $25(\mathrm{OH}) \mathrm{D}$ concentrations above $58 \mathrm{nmol} / \mathrm{L}$ increases and the proportion with concentrations below $171 \mathrm{nmol} / \mathrm{L}$ decreases. Supplementation of 12864 $(9930-19,067)$ IU per day is needed to achieve that $97.5 \%$ of participants reach $58 \mathrm{nmol} / \mathrm{L}$ or more. At this supplementation level $34 \%$ of participants will reach serum $25(\mathrm{OH}) \mathrm{D}$ concentrations in excess of the upper limit of the natural range $(171 \mathrm{nmol} / \mathrm{L})$. The blue line in Figure 3 represents the proportion 
of participants that have serum concentrations above $58 \mathrm{nmol} / \mathrm{L}$ and below $171 \mathrm{nmol} / \mathrm{L}$. This line is curved and shows that the proportion above $58 \mathrm{nmol} / \mathrm{L}$ and below $171 \mathrm{nmol} / \mathrm{L}$ peaks at $87 \%$ at a supplementation dose of 2745 (2616-3147) IU per day. This peak represents the optimal supplementation dose. At this optimal dose, $8 \%$ will have serum $25(\mathrm{OH}) \mathrm{D}$ concentrations below 58 $\mathrm{nmol} / \mathrm{L}$ and $5 \%$ in excess of $171 \mathrm{nmol} / \mathrm{L}$ (Figure 3).

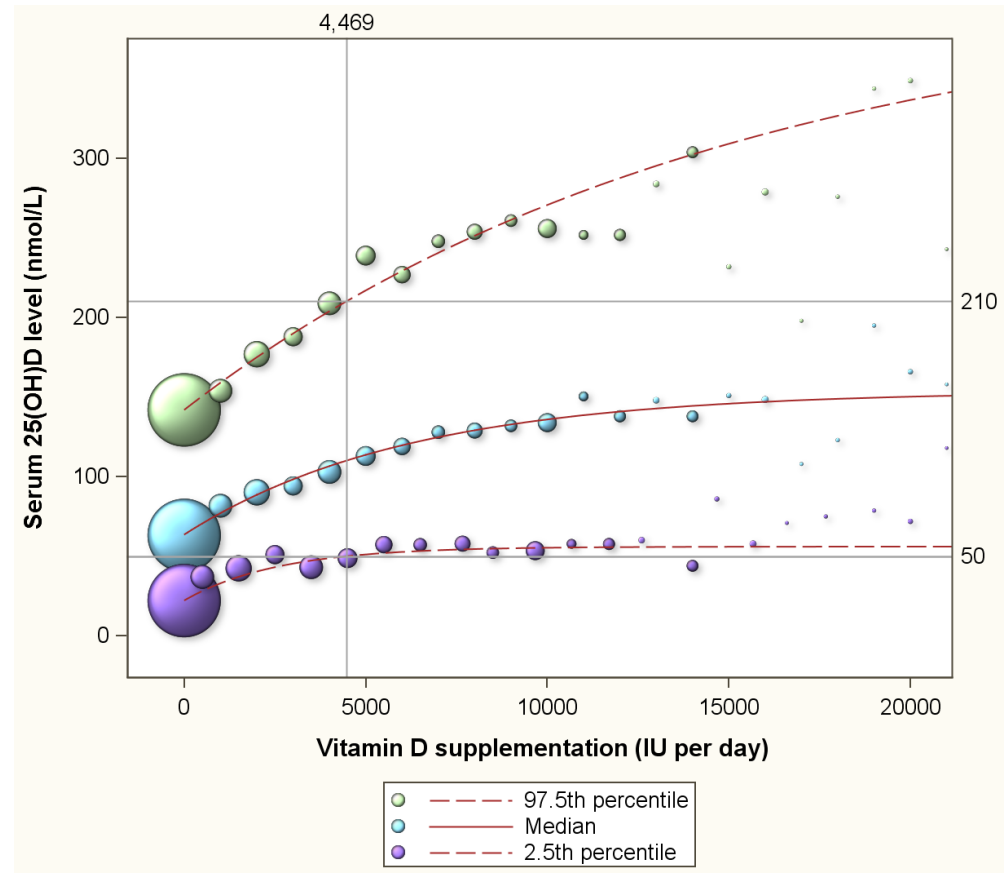

Figure 2. The median and 2.5th and 97.5th percentiles of serum $25(\mathrm{OH}) \mathrm{D}$ concentrations by vitamin D supplementation among 11,693 healthy participants of a preventive health program in Canada. Note: The 2.5 percentile line depicts $25(\mathrm{OH}) \mathrm{D}$ concentrations for any given vitamin $\mathrm{D}$ supplementation dose with $2.5 \%$ of all expected $25(\mathrm{OH}) \mathrm{D}$ responses to have values below the line, and $97.5 \%$ to have values above the line. The 97.5 percentile line depicts $25(\mathrm{OH}) \mathrm{D}$ concentrations for any given vitamin D supplementation dose with $97.5 \%$ of all expected $25(\mathrm{OH}) \mathrm{D}$ responses to have values below the line, and $2.5 \%$ to have values above the line. The area between the 2.5 percentile line and the 97.5 percentile line depicts the $95 \%$ prediction interval of $25(\mathrm{OH}) \mathrm{D}$ concentrations for any given vitamin $\mathrm{D}$ supplementation dose. The median, the 2.5 th and 97.5 th percentiles were estimated through quantile regression, a statistical approach that accommodates the clearly visible skewness in the distribution of $25(\mathrm{OH}) \mathrm{D}$ concentrations.

Figure 4 is a repeat of Figure 3 for normal weight, overweight and obese subgroups. Optimum proportions of participants with natural serum $25(\mathrm{OH}) \mathrm{D}$ concentrations are reached with supplementation with 1885 (1518-2166), 2802 (2400-3666) and 6235 (5943-7004) for normal weight, overweight and obese participants respectively. The lower target of $58 \mathrm{nmol} / \mathrm{L}$ and the upper target of $171 \mathrm{nmol} / \mathrm{L}$ applied in figures 3 and 4 were just examples to illustrate the concept. Table 2 presents for several combinations of lower and upper serum $25(\mathrm{OH}) \mathrm{D}$ targets the vitamin $\mathrm{D}$ supplementation needed to maximize the probability to achieve serum $25(\mathrm{OH}) \mathrm{D}$ concentrations between the lower and upper target. 


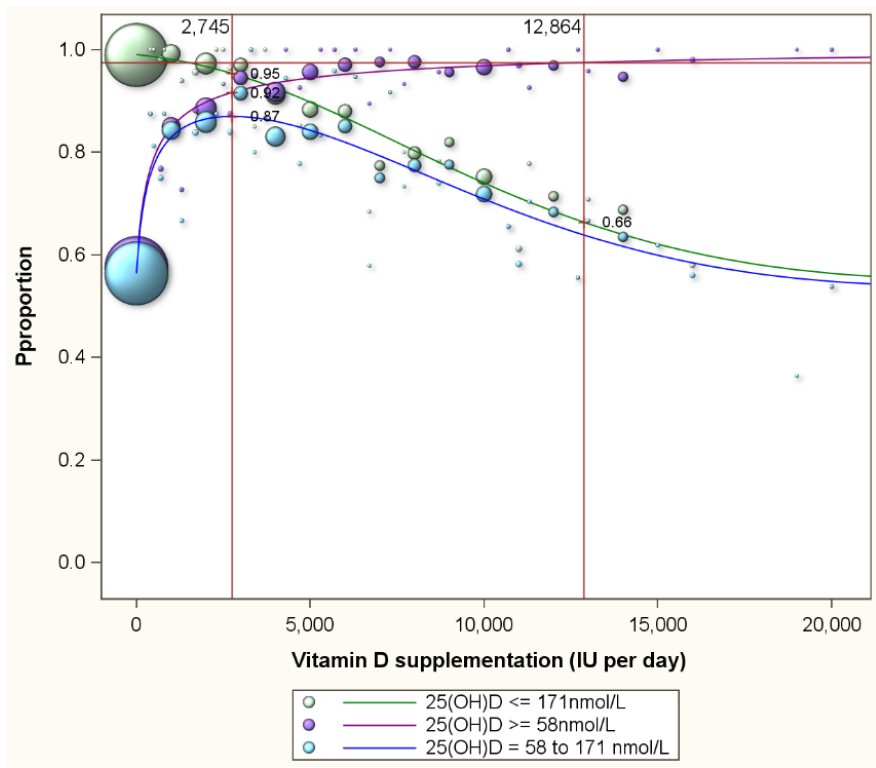

Figure 3. Proportion of participants with serum 25(OH)D concentrations above the lower natural limit, below the upper natural limit and within the natural range. Note: The purple line represents the proportion of individuals with serum $25(\mathrm{OH}) \mathrm{D}$ concentrations of $58 \mathrm{nmol} / \mathrm{L}$ or more by vitamin D supplementation level; the green line the proportion of participants with concentrations of $171 \mathrm{nmol} / \mathrm{L}$ or less; and the blue line the proportion of participants that have serum concentrations above $58 \mathrm{nmol} / \mathrm{L}$ and below $171 \mathrm{nmol} / \mathrm{L}$. The blue line is curved and shows that the proportion above $58 \mathrm{nmol} / \mathrm{L}$ and below $171 \mathrm{nmol} / \mathrm{L}$ peaks at $87 \%$ at a supplementation dose of $2745 \mathrm{IU}$ per day. At this optimal dose, $8 \%(100 \%-92 \%)$ will have serum $25(\mathrm{OH}) \mathrm{D}$ concentrations below $58 \mathrm{nmol} / \mathrm{L}$ and $5 \%(100 \%-95 \%)$ in excess of $171 \mathrm{nmol} / \mathrm{L}$.

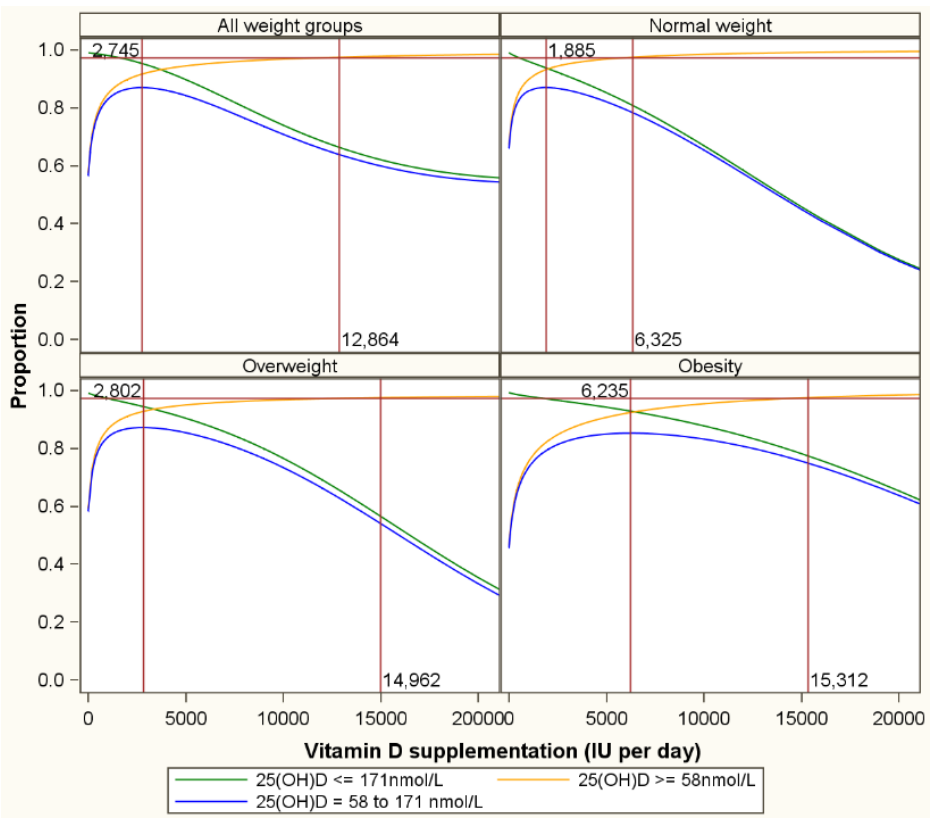

Figure 4. Proportion of participants with serum $25(\mathrm{OH}) \mathrm{D}$ concentrations above the lower natural limit, below the upper natural limit and within the natural range by body weight status. Note: The orange lines represent the proportion of individuals with serum $25(\mathrm{OH}) \mathrm{D}$ concentrations of $58 \mathrm{nmol} / \mathrm{L}$ or more by vitamin D supplementation level; the green lines the proportion of participants with concentrations of $171 \mathrm{nmol} / \mathrm{L}$ or less; and the blue lines the proportion of participants that have serum concentrations above $58 \mathrm{nmol} / \mathrm{L}$ and below $171 \mathrm{nmol} / \mathrm{L}$. 
Table 2. Vitamin D supplementation that maximizes the proportion of participants with serum $25(\mathrm{OH}) \mathrm{D}$ concentrations within various lower and upper serum 25(OH)D targets.

\begin{tabular}{|c|c|c|c|c|c|c|c|c|c|c|c|c|c|c|c|c|c|c|c|c|c|c|c|c|c|c|}
\hline \multirow{4}{*}{\multicolumn{3}{|c|}{$s$}} & \multicolumn{24}{|c|}{ LOWER SERUM 25(OH)D TARGETS (in nmol/L) } \\
\hline & & & \multicolumn{4}{|c|}{40} & \multirow{2}{*}{\multicolumn{4}{|c|}{$\begin{array}{l}50 \\
\text { Proportion }\end{array}$}} & \multicolumn{4}{|c|}{58} & \multicolumn{4}{|c|}{75} & \multicolumn{4}{|c|}{100} & \multicolumn{4}{|c|}{150} \\
\hline & & & \multicolumn{4}{|c|}{ Proportion } & & \multicolumn{3}{|c|}{ Proportion } & \multicolumn{4}{|c|}{ Proportion } & \multicolumn{4}{|c|}{ Proportion } & \multicolumn{4}{|c|}{ Proportion } & \multicolumn{4}{|c|}{ Proportion } \\
\hline & & & $\begin{array}{c}\text { Optimal } \\
\text { Intake } \\
\text { (IU) }\end{array}$ & $\begin{array}{c}\text { Between } \\
\text { Lower } \\
\text { and } \\
\text { Upper }\end{array}$ & $\begin{array}{l}\text { Above } \\
\text { Lower }\end{array}$ & $\begin{array}{l}\text { Below } \\
\text { Upper }\end{array}$ & $\begin{array}{c}\text { Optimal } \\
\text { Intake } \\
\text { (IU) }\end{array}$ & $\begin{array}{c}\text { Between } \\
\text { Lower } \\
\text { and } \\
\text { Upper } \\
\end{array}$ & $\begin{array}{l}\text { Above } \\
\text { Lower }\end{array}$ & $\begin{array}{l}\text { Below } \\
\text { Upper }\end{array}$ & $\begin{array}{c}\text { Optimal } \\
\text { Intake } \\
\text { (IU) }\end{array}$ & $\begin{array}{c}\text { Between } \\
\text { Lower } \\
\text { and } \\
\text { Upper }\end{array}$ & $\begin{array}{l}\text { Above } \\
\text { Lower }\end{array}$ & $\begin{array}{l}\text { e Below } \\
\text { r Upper }\end{array}$ & $\begin{array}{c}\text { Optimal } \\
\text { Intake } \\
(I U)\end{array}$ & $\begin{array}{c}\text { Between } \\
\text { Lower } \\
\text { and } \\
\text { Upper }\end{array}$ & $\begin{array}{l}\text { Above } \\
\text { Lower }\end{array}$ & $\begin{array}{l}\text { Below } \\
\text { Upper }\end{array}$ & $\begin{array}{c}\text { Optimal } \\
\text { Intake } \\
\text { (IU) }\end{array}$ & $\begin{array}{c}\text { Between } \\
\text { Lower } \\
\text { and } \\
\text { Upper }\end{array}$ & $\begin{array}{l}\text { Above } \\
\text { Lower }\end{array}$ & Below & $\begin{array}{c}\text { Optimal } \\
\text { Intake } \\
\text { (IU) }\end{array}$ & $\begin{array}{c}\text { Between } \\
\text { Lower } \\
\text { and } \\
\text { Upper }\end{array}$ & $\begin{array}{l}\text { Above } \\
\text { Lower }\end{array}$ & $\begin{array}{l} \\
\text { ee Belou } \\
\text { er Upper }\end{array}$ \\
\hline \multirow{17}{*}{ 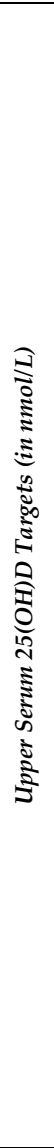 } & 100 & $\begin{array}{c}\text { Normal } \\
\text { weight }\end{array}$ & 104 & 0.70 & 0.91 & 0.79 & 238 & 0.63 & 0.87 & 0.76 & 377 & 0.56 & 0.83 & 0.73 & 837 & 0.36 & 0.70 & 0.66 & & & & & & & & \\
\hline & & $\begin{array}{c}\text { Overwe } \\
\text { ight }\end{array}$ & 129 & 0.74 & 0.90 & 0.84 & 301 & 0.65 & 0.85 & 0.79 & 513 & 0.57 & 0.81 & 0.75 & 1108 & 0.36 & 0.69 & 0.67 & & & & & & & & \\
\hline & & Obesity & 364 & 0.77 & 0.91 & 0.87 & 755 & 0.66 & 0.84 & 0.82 & 1177 & 0.55 & 0.77 & 0.77 & 2603 & 0.31 & 0.64 & 0.67 & & & & & & & & \\
\hline & & $\begin{array}{c}\text { All } \\
\text { weight } \\
\text { groups }\end{array}$ & 349 & 0.77 & 0.93 & 0.84 & 552 & 0.69 & 0.88 & 0.81 & 719 & 0.61 & 0.82 & 0.79 & 1048 & 0.41 & 0.65 & 0.75 & & & & & & & & \\
\hline & 125 & $\begin{array}{c}\text { Normal } \\
\text { weight }\end{array}$ & 323 & 0.85 & 0.95 & 0.90 & 606 & 0.79 & 0.92 & 0.87 & 886 & 0.74 & 0.89 & 0.85 & 1798 & 0.58 & 0.79 & 0.79 & & & & & & & & \\
\hline & & $\begin{array}{c}\text { Overwe } \\
\text { ight }\end{array}$ & 622 & 0.88 & 0.96 & 0.93 & 939 & 0.83 & 0.92 & 0.91 & 1209 & 0.78 & 0.88 & 0.90 & 1808 & 0.61 & 0.75 & 0.86 & & & & & & & & \\
\hline & & Obesity & 830 & 0.87 & 0.94 & 0.93 & 1717 & 0.79 & 0.90 & 0.89 & 2683 & 0.71 & 0.85 & 0.85 & 4960 & 0.52 & 0.74 & 0.78 & & & & & & & & \\
\hline & & $\begin{array}{c}\text { All } \\
\text { weight } \\
\text { groups }\end{array}$ & 669 & 0.88 & 0.96 & 0.93 & 1025 & 0.82 & 0.92 & 0.91 & 1322 & 0.76 & 0.87 & 0.89 & 1941 & 0.59 & 0.73 & 0.86 & 4138 & 0.27 & 0.57 & 0.70 & & & & \\
\hline & 150 & $\begin{array}{c}\text { Normal } \\
\text { weight }\end{array}$ & 499 & 0.91 & 0.96 & 0.95 & 889 & 0.87 & 0.94 & 0.93 & 1280 & 0.82 & 0.91 & 0.91 & 2650 & 0.68 & 0.83 & 0.85 & 6208 & 0.44 & 0.74 & 0.71 & & & & \\
\hline & & $\begin{array}{c}\text { Overwe } \\
\text { ight }\end{array}$ & 731 & 0.91 & 0.96 & 0.95 & 1274 & 0.86 & 0.93 & 0.93 & 1779 & 0.82 & 0.90 & 0.92 & 3156 & 0.68 & 0.81 & 0.87 & 6479 & 0.42 & 0.67 & 0.76 & & & & \\
\hline & & Obesity & 1620 & 0.92 & 0.97 & 0.96 & 3181 & 0.87 & 0.94 & 0.93 & 4640 & 0.81 & 0.90 & 0.91 & 7250 & 0.66 & 0.80 & 0.86 & 9862 & 0.40 & 0.61 & 0.80 & & & & \\
\hline & & $\begin{array}{c}\text { All } \\
\text { weight } \\
\text { groups }\end{array}$ & 1012 & 0.93 & 0.97 & 0.96 & 1535 & 0.88 & 0.94 & 0.95 & 1978 & 0.83 & 0.90 & 0.94 & 2949 & 0.68 & 0.78 & 0.90 & 5643 & 0.44 & 0.65 & 0.78 & & & & \\
\hline & 171 & $\begin{array}{c}\text { Normal } \\
\text { weight }\end{array}$ & 774 & 0.94 & 0.97 & 0.97 & 1340 & 0.90 & 0.95 & 0.95 & 1885 & 0.87 & 0.93 & 0.94 & 3656 & 0.75 & 0.86 & 0.89 & 7209 & 0.55 & 0.78 & 0.78 & & & & \\
\hline & & $\begin{array}{c}\text { Overwe } \\
\text { ight }\end{array}$ & 1276 & 0.94 & 0.97 & 0.97 & 2114 & 0.91 & 0.95 & 0.96 & 2802 & 0.87 & 0.93 & 0.94 & 4611 & 0.76 & 0.85 & 0.91 & 8270 & 0.55 & 0.73 & 0.82 & & & & \\
\hline & & Obesity & 2243 & 0.94 & 0.97 & 0.97 & 4344 & 0.90 & 0.95 & 0.95 & 6235 & 0.85 & 0.92 & 0.93 & 9451 & 0.73 & 0.84 & 0.89 & 12,843 & 0.50 & 0.67 & 0.83 & & & & \\
\hline & & $\begin{array}{c}\text { All } \\
\text { weight } \\
\text { groups }\end{array}$ & 1414 & 0.95 & 0.97 & 0.98 & 2133 & 0.91 & 0.95 & 0.96 & 2745 & 0.87 & 0.92 & 0.95 & 4108 & 0.74 & 0.82 & 0.92 & 6829 & 0.54 & 0.70 & 0.84 & 10,373 & 0.14 & 0.41 & 0.73 \\
\hline & 200 & $\begin{array}{c}\text { Normal } \\
\text { weight }\end{array}$ & 1199 & 0.96 & 0.98 & 0.98 & 2038 & 0.94 & 0.97 & 0.97 & 2849 & 0.91 & 0.95 & 0.96 & 5479 & 0.82 & 0.90 & 0.92 & 10,008 & 0.69 & 0.86 & 0.83 & & & & \\
\hline
\end{tabular}


Table 2. Cont.

\begin{tabular}{|c|c|c|c|c|c|c|c|c|c|c|c|c|c|c|c|c|c|c|c|c|c|c|c|c|c|}
\hline \multirow{11}{*}{ 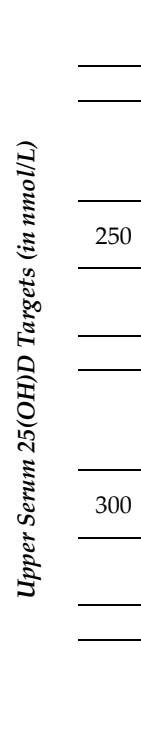 } & $\begin{array}{c}\text { Overwe } \\
\text { ight }\end{array}$ & 2082 & 0.96 & 0.98 & 0.98 & 3321 & 0.94 & 0.96 & 0.97 & 4250 & 0.91 & 0.94 & 0.96 & 6702 & 0.82 & 0.88 & 0.94 & 11,120 & 0.67 & 0.80 & 0.87 & & & & \\
\hline & Obesity & 3527 & 0.96 & 0.98 & 0.98 & 6386 & 0.94 & 0.97 & 0.97 & 8714 & 0.90 & 0.95 & 0.95 & 12,365 & 0.80 & 0.88 & 0.92 & 16,112 & 0.60 & 0.73 & 0.87 & & & & \\
\hline & $\begin{array}{c}\text { All } \\
\text { weight } \\
\text { groups }\end{array}$ & 1883 & 0.96 & 0.98 & 0.98 & 3243 & 0.93 & 0.96 & 0.97 & 4491 & 0.90 & 0.94 & 0.96 & 7297 & 0.80 & 0.87 & 0.93 & 9423 & 0.66 & 0.76 & 0.90 & 12,627 & 0.30 & 0.46 & 0.84 \\
\hline & $\begin{array}{c}\text { Normal } \\
\text { weight }\end{array}$ & 2319 & 0.98 & 0.99 & 0.99 & 3971 & 0.96 & 0.98 & 0.98 & 5433 & 0.95 & 0.97 & 0.98 & & & & & & & & & & & & \\
\hline & $\begin{array}{c}\text { Overwe } \\
\text { ight }\end{array}$ & 3980 & 0.98 & 0.99 & 0.99 & 5981 & 0.96 & 0.98 & 0.99 & 7281 & 0.94 & 0.96 & 0.98 & & & & & & & & & & & & \\
\hline & Obesity & 5433 & 0.98 & 0.99 & 0.99 & 11,402 & 0.96 & 0.99 & 0.98 & 16,917 & 0.95 & 0.98 & 0.97 & & & & & & & & & & & & \\
\hline & $\begin{array}{c}\text { All } \\
\text { weight } \\
\text { groups }\end{array}$ & 3543 & 0.98 & 0.99 & 0.99 & 5918 & 0.96 & 0.98 & 0.98 & 7914 & 0.94 & 0.96 & 0.98 & 11,972 & 0.87 & 0.92 & 0.96 & 11,922 & 0.74 & 0.78 & 0.96 & 15,623 & 0.43 & 0.50 & 0.93 \\
\hline & $\begin{array}{c}\text { Normal } \\
\text { weight }\end{array}$ & 3307 & 0.99 & 0.99 & 1.00 & 5228 & 0.98 & 0.98 & 0.99 & & & & & & & & & & & & & & & & \\
\hline & $\begin{array}{c}\text { Overwe } \\
\text { ight }\end{array}$ & 5,042 & 0.98 & 0.99 & 0.99 & 7433 & 0.97 & 0.98 & 0.99 & & & & & & & & & & & & & & & & \\
\hline & Obesity & 8767 & 0.99 & 0.99 & 1.00 & 13,065 & 0.98 & 0.99 & 0.99 & & & & & & & & & & & & & & & & \\
\hline & $\begin{array}{c}\text { All } \\
\text { weight } \\
\text { groups }\end{array}$ & 5163 & 0.98 & 0.99 & 0.99 & 8225 & 0.97 & 0.98 & 0.99 & 10,560 & 0.96 & 0.97 & 0.99 & 14,955 & 0.90 & 0.93 & 0.97 & 13,049 & 0.77 & 0.79 & 0.98 & 16,859 & 0.47 & 0.51 & 0.96 \\
\hline
\end{tabular}

Note: Where the number of observations with serum 25(OH)D concentrations was limited we were not able to provide accurate estimates for weight specific estimates for optimal intake. 


\section{Discussion}

The aggregation of published estimates revealed that $2990 \mathrm{IU}$ per day is needed to achieve serum $25(\mathrm{OH}) \mathrm{D}$ concentrations of $50 \mathrm{nmol} / \mathrm{L}$ or more in $97.5 \%$ of healthy individuals. For normal weight participants of the preventive health program this was $3094 \mathrm{IU}$ per day. These estimates are in excess of the current recommendation of $600 \mathrm{IU}$ per day.

Despite the current recommendations, vitamin D deficiency constitutes a tremendous public health burden. According to Statistics Canada the percentage of Canadians having serum 25(OH)D concentrations below $50 \mathrm{nmol} / \mathrm{L}$ is $35 \%$ [53]. Among Canadians who take vitamin D supplementation, $15 \%$ had serum $25(\mathrm{OH}) \mathrm{D}$ concentrations below $50 \mathrm{nmol} / \mathrm{L}$ [8]. Among older Canadian residing in urban areas and supplementing with $400 \mathrm{IU}$ per day or more, $10 \%$ had serum $25(\mathrm{OH}) \mathrm{D}$ concentrations below $50 \mathrm{nmol} / \mathrm{L}$ [9]. These observations show that the current recommendation is failing the objective of preventing vitamin D deficiency and thus in need of reconsideration. The objective of the present study is to inform this reconsideration. The objective of the present study is not to recommend specific supplementation regimens or specific $25(\mathrm{OH}) \mathrm{D}$ targets.

Serum $25(\mathrm{OH}) \mathrm{D}$ concentrations are affected by various host and environmental factors including age, sex, diet, sun exposure, physical activity, body weight, skin pigmentation, genetic factors, among others $[4,54,55]$. Body weight appeared to have a profound effect on the dose response relationship between vitamin intake and $25(\mathrm{OH}) \mathrm{D}$ such that overweight and obese individuals are recommended respectively 1.5 and two to three times more vitamin D than normal weight subjects[3,4]. Sun exposure, responsible for the endogenous synthesis of vitamin $\mathrm{D}$, varies by latitude and season. In the present study, we revealed that relative to observations between $50^{\circ} \mathrm{S}$ and $50^{\circ} \mathrm{N}$, participants of studies above $50^{\circ} \mathrm{N}$ had $25(\mathrm{OH}) \mathrm{D}$ concentrations that were on average approximately $10 \mathrm{nmol} / \mathrm{L}$ lower. This relative modest variation by latitude seems consistent with observations of others [56-58], but may represent an underestimation resulting from the fact that latitude is a poor proxy of actual sun exposure and endogenous synthesis of vitamin D. This may also apply to season as a proxy of sun exposure and endogenous synthesis of vitamin D. Modest variation in $25(\mathrm{OH}) \mathrm{D}$ concentrations will also arise from dietary vitamin $\mathrm{D}$ as the vitamin $\mathrm{D}$ content of diets is relatively low. For example, the Canadian diet of adults contains on average 232 IU of vitamin D [59] and that of children on average $167 \mathrm{IU}$ with fortified foods as the primary contributors [60]. British diets reportedly contain $124 \mathrm{IU}$ and $28 \mathrm{IU}$ per day for meat eaters and vegans respectively [61]. Clearly, such relative small quantities of dietary vitamin $\mathrm{D}$ are unlikely to introduce large variability in $25(\mathrm{OH}) \mathrm{D}$ concentrations. It has also been suggested that $25(\mathrm{OH}) \mathrm{D}$ in meat affects the consumer's serum $25(\mathrm{OH}) \mathrm{D}$ concentration and herewith contributes to the variability in the dose response relationship between vitamin $\mathrm{D}$ intake and serum 25(OH)D concentrations [61]. It has further been suggested that the fat content of the diet has a profound effect on the absorption of vitamin D supplementation and herewith may introduce variability in the dose response relationship between vitamin $\mathrm{D}$ intake and $25(\mathrm{OH}) \mathrm{D}$ concentrations [62-64]. Furthermore, in addition to the abovementioned host factors, various genetic factors have been suggested to introduce variability in $25(\mathrm{OH}) \mathrm{D}$ concentrations [65-73]. We should also recognize that the way studies were executed may affect the study outcomes. The minimum period between commencing supplementation and assessing $25(\mathrm{OH}) \mathrm{D}$ concentrations should be in excess of three months as illustrated in the present study. Other aspects of research that may affect outcomes include participants' compliance with supplementation regimens, reporting bias and the laboratory assessment methods.

Collectively, the abovementioned host and environmental factors are responsible for large variability in serum $25(\mathrm{OH}) \mathrm{D}$ concentrations in the general population. Large variability also exists for the bodily responses to vitamin $\mathrm{D}$ intake as revealed in the present study. Our literature review had revealed standard deviations of $25(\mathrm{OH}) \mathrm{D}$ responses to vitamin D intake for 108 study doses. These standard deviations ranged from 6.6 to 97.5 with an average value of 19.9 and a median value of $17.8 \mathrm{nmol} / \mathrm{L}$ (Appendix). This large variation is responsible for the fact that high supplementation doses are needed to ensure that $97.5 \%$ of subjects achieve serum $25(\mathrm{OH}) \mathrm{D}$ concentrations above relatively modest targets, while other subjects will reach high $25(\mathrm{OH}) \mathrm{D}$ concentrations at modest supplementation levels. For example, the present study illustrated that $2.5 \%$ of normal weight 
subjects would reach serum $25(\mathrm{OH}) \mathrm{D}$ concentrations above $210 \mathrm{nmol} / \mathrm{L}$ with the supplementation dose of $3094 \mathrm{IU}$ per day, which is the dose needed to ensure that $97.5 \%$ of subjects have serum levels above $50 \mathrm{nmol} / \mathrm{L}$. Hence, if one judges serum 25(OH)D concentrations in excess of $210 \mathrm{nmol} / \mathrm{L}$ as undesirable, a target to achieve serum levels above $50 \mathrm{nmol} / \mathrm{L}$ in $97.5 \%$ of a population would not be feasible because $2.5 \%$ would end up with serum concentrations that some will judge as undesirably high. An approach that seeks an optimal supplementation dose that minimizes both low and high $25(\mathrm{OH}) \mathrm{D}$ concentrations seems therefore preferable. The present study is the first to take that approach.

Our literature review had identified standard deviations of $25(\mathrm{OH}) \mathrm{D}$ responses to vitamin $\mathrm{D}$ intake that ranged from 6.6 to $97.5 \mathrm{nmol} / \mathrm{L}$ and had a median value of $17.8 \mathrm{nmol} / \mathrm{L}$ [17-52]. The standard deviation is also considered in the calculation of the RDA[1]. Specifically, the RDA represents the amount of vitamin $\mathrm{D}$ that is two standard deviations above the amount that meets the needs of $50 \%$ of the population at large. The IOM, in their calculations of the RDA, had assumed too low a value for this standard deviation by mistakenly using standard error where standard deviation should have been used [1,10,11], and, in their recent announcement, had applied the value of $2 \mathrm{ng} / \mathrm{mL}$ $(5 \mathrm{nmol} / \mathrm{L})$ as standard deviation which is lower than any existing estimate for standard deviation [74]. The 108 existing estimates range from 6.6 to $97.5 \mathrm{nmol} / \mathrm{L}$ with a median value of $17.8 \mathrm{nmol} / \mathrm{L}$ [17-52]. Clearly, had the IOM used any of the existing standard deviations, they would have estimated a higher RDA. Specifically, the IOM suggested $400 \mathrm{IU}$ per day as the amount of vitamin D that meets the needs of $50 \%$ of the population [1]. With the assumption that $400 \mathrm{IU}$ per day achieves an average serum $25(\mathrm{OH}) \mathrm{D}$ concentration of $40 \mathrm{nmol} / \mathrm{L}[1]$, the present analysis shows that $1229 \mathrm{IU}$ per day is needed to achieve that $97.5 \%$ of the population has $25(\mathrm{OH}) \mathrm{D}$ concentrations of $40 \mathrm{nmol} / \mathrm{L}$ or more. However, others have argued that the recommendation of $400 \mathrm{IU}$ per day as the dose that meets the needs of $50 \%$ of the population is too low [2,3,75-77]. Higher values for the amount of vitamin D that meet the needs of $50 \%$ of the population will come with progressively higher values for the amount that meets the needs for $97.5 \%$ of the population.

Benefits of vitamin D supplementation have been suggested for the prevention of fractures in the elderly [78,79], reduction of risk for metabolic syndrome and insulin resistance [13,80], reduction of adverse cardiovascular events [81,82], prevention of cancer [34,83-88], multiple sclerosis [89], and improvements in immune function [90-92]. Several well powered, long term randomized clinical trials with supplementation doses of up to 3,200 IU per day are currently underway [93]. Where these reveal positive results and where these lead to recommendations to adjust the current RDA, our observations suggest two considerations: (1) that not only a lower serum $25(\mathrm{OH}) \mathrm{D}$ target is considered but an upper serum 25(OH)D target as well; and (2) the new recommendations be body weight status specific.

Various studies, including some reported recently, have suggested adverse effects of high serum 25(OH)D concentrations[94-98]. Other recent studies have suggested the absence of associations of vitamin D supplementation and serum $25(\mathrm{OH}) \mathrm{D}$ concentrations with hypercalcemia $[4,99]$ adding to interpretations that adverse effects from vitamin D doses of up to 50,000 IU per day are very rare $[100,101]$ and that "vitamin D is not as toxic as was once thought" [102]. In the present study, very few subjects develop 25(OH)D concentrations in excess of $300 \mathrm{nmol} / \mathrm{L}$. For this reason it appeared very challenging to model the probability of targets higher than $300 \mathrm{nmol} / \mathrm{L}$. Whether $300 \mathrm{nmol} / \mathrm{L}$, or lower or higher serum concentrations, should be set as the upper target to ensure safety is beyond the scope of the present study. Likewise, advising on supplementation and $25(\mathrm{OH}) \mathrm{D}$ concentrations to achieve specific health benefits, is beyond the scope of the present study. In this respect, a recent review of the literature concluded that specific health conditions may be prevented at distinct serum 25(OH)D concentrations [103].

A strength of the present study is its dual approach that included a meta analysis of randomized controlled trials of vitamin D supplementation and an analysis of a large preventive health program with subjects using a wide range of vitamin D supplementation and with information on various host and environmental factors allowing us to adjust for their confounding influence. We acknowledge that vitamin $\mathrm{D}$ studies are difficult to generalize because vitamin $\mathrm{D}$ status is determined by so many host and environmental factors. This applies to the randomized controlled trials included in our meta 
analysis and our analysis of the program participants. As a limitation of the meta analysis we further acknowledge our inability to stratify or adjust for body weight which is an critical determinant. As a limitation of the preventive health program we further acknowledge the presence of selection bias as health conscious individuals are more likely to participate in a volunteer program [14]. Moreover, our meta analysis likely generated biased estimates for the 2.5th and 97.5th percentiles as our analysis of program participants had revealed a high degree of skewness in the distribution of serum $25(\mathrm{OH}) \mathrm{D}$ concentrations (Figure 2). This limitation extends to all studies that assume a normal distribution of serum $25(\mathrm{OH}) \mathrm{D}$ concentrations. However, despite the abovementioned limitations and sources of bias, estimates for the 2.5th percentiles from our meta analysis and our analysis of the program participants produce relatively similar findings.

\section{Conclusions}

In conclusion, we revealed a very large variation in $25(\mathrm{OH}) \mathrm{D}$ concentrations in response to vitamin D intake. This large variation is responsible for the fact that relative high supplementation doses are needed to ensure that the majority of the general population achieves at least modest serum $25(\mathrm{OH}) \mathrm{D}$ concentrations while other subjects will reach high $25(\mathrm{OH}) \mathrm{D}$ concentrations at modest supplementation levels. For example, where one judges serum $25(\mathrm{OH}) \mathrm{D}$ concentrations in excess of $210 \mathrm{nmol} / \mathrm{L}$ as undesirably high, a dose recommendation to ensure $25(\mathrm{OH}) \mathrm{D}$ concentrations above 50 $\mathrm{nmol} / \mathrm{L}$ in $97.5 \%$ of the general population is not feasible because more than $2.5 \%$ of subjects will end up with serum concentrations that some judge as undesirable. We therefore recommend an approach that seeks an optimal supplementation dose that minimizes the risk for both low and high $25(\mathrm{OH}) \mathrm{D}$ concentrations. We further recommend these optimal doses be body weight specific.

Supplementary materials: Supplementary materials can be accessed at: http://www.mdpi.com/2072$6643 / 7 / 12 / 5527 / s 1$.

Acknowledgments: The authors wish to thank the Pure North S'Energy Foundation for allowing their data to be analyzed for the purpose of this article. They specifically wish to thank Peter Tran and Ken Fyle for management and validation of the Foundation's data. P.J.V. holds a Canada Research Chair in Population Health, an Alberta Research Chair in Nutrition and Disease Prevention, and an Alberta Innovates Health Scholarship. The funding for the Canada Research Chair is provided through the Canadian Institutes for Health Research to the University of Alberta. The Alberta Research Chair is awarded by the School of Public Health at the University of Alberta through a thematic research contract with the Pure North S'Energy Foundation. The Alberta Innovates Health Scholarship is funded by the Alberta provincial government through Alberta Innovates Health Solutions to the University of Alberta.

Authors Contributions: The authors' contributions are as follows: J.P.E. and T.-M.P. conducted the literature review; J.P.E. performed the statistical analyses; J.P.E. and P.J.V. articulated the study hypothesis, decided on the analytic approach, interpreted the data and wrote the manuscript; J.P.E., T.-M.P. and P.J.V. approved the final version of the manuscript.

Conflict of interest: The authors declare no conflict of interest.

\section{Appendix}

Studies that reported both the mean and standard deviation of serum $25(\mathrm{OH}) \mathrm{D}$ concentrations by vitamin D intake.

\begin{tabular}{|c|c|c|c|c|c|c|c|c|}
\hline Study & $\begin{array}{c}\text { Gender of } \\
\text { Participants }\end{array}$ & $\begin{array}{l}\text { Vitamin D } \\
\text { Supplement }\end{array}$ & $\begin{array}{c}\text { Sub } \\
\text { Group }\end{array}$ & $\begin{array}{l}\text { Dose } \\
\text { (IU) }\end{array}$ & $\begin{array}{c}\text { Follow } \\
\text { Up in } \\
\text { Weeks }\end{array}$ & $\begin{array}{c}\text { Number of } \\
\text { Participants }\end{array}$ & $\begin{array}{c}\text { Mean } \\
25(\mathrm{OH}) \mathrm{D} \\
\text { in nmol/L }\end{array}$ & $\begin{array}{c}\text { SD in } \\
\text { nmol/L }\end{array}$ \\
\hline \multirow[t]{2}{*}{$\begin{array}{l}\text { Ala-Houhala, M., } \\
\text { et al., } 1988 \text { [17] }\end{array}$} & Both & None & & 0 & 52 & 27 & 43.3 & 19.5 \\
\hline & & $\begin{array}{c}\text { Not } \\
\text { specified }\end{array}$ & & 400 & 52 & 24 & 71.3 & 23.8 \\
\hline $\begin{array}{c}\text { Aloia, J., et al., } \\
2010 \text { [18] }\end{array}$ & Both & D3 & & 4000 & 13 & 35 & 111.7 & 30.0 \\
\hline
\end{tabular}


Appendix. Cont.

\begin{tabular}{|c|c|c|c|c|c|c|c|c|}
\hline $\begin{array}{c}\text { Aloia, J.F., et al., } \\
2005 \text { [19] }\end{array}$ & Female & D3 & & 800 & 13 & 104 & 70.8 & 22.9 \\
\hline \multirow[t]{5}{*}{$\begin{array}{l}\text { Biancuzzo, R.M., } \\
\text { et al., } 2010 \text { [20] }\end{array}$} & Both & None & & 0 & 11 & 17 & 45.3 & 16.0 \\
\hline & & D3 & $\begin{array}{l}\text { In orange } \\
\text { juice }\end{array}$ & 1000 & 11 & 16 & 76.8 & 21.3 \\
\hline & & & $\begin{array}{c}\text { In } \\
\text { capsules }\end{array}$ & 1000 & 11 & 18 & 70.0 & 27.5 \\
\hline & & D2 & $\begin{array}{l}\text { In orange } \\
\text { juice }\end{array}$ & 1000 & 11 & 20 & 66.0 & 18.5 \\
\hline & & & $\begin{array}{c}\text { In } \\
\text { capsules }\end{array}$ & 1000 & 11 & 15 & 68.5 & 26.3 \\
\hline \multirow[t]{6}{*}{$\begin{array}{l}\text { Bolton-Smith, C., } \\
\text { et al., } 2007 \text { [21] }\end{array}$} & Female & None & & 0 & 52 & 55 & 47.8 & 17.3 \\
\hline & & & & & 104 & 55 & 48.8 & 13.3 \\
\hline & & D3 & $\begin{array}{l}\text { Vit D + } \\
\text { Calcium }\end{array}$ & 400 & 52 & 55 & 74.3 & 15.3 \\
\hline & & & & & 104 & 55 & 74.5 & 15.0 \\
\hline & & & $\begin{array}{l}\text { Vit D + } \\
\text { Vit K+ } \\
\text { Calcium }\end{array}$ & 400 & 52 & 58 & 73.0 & 16.3 \\
\hline & & & & & 104 & 58 & 70.8 & 16.5 \\
\hline \multirow[t]{4}{*}{$\begin{array}{l}\text { Cashman, K.D., } \\
\text { et al., } 2012 \text { [22] }\end{array}$} & Both & None & & 0 & 5 & 13 & 39.7 & 11.1 \\
\hline & & & & & 10 & 13 & 41.2 & 11.1 \\
\hline & & D3 & & 800 & 5 & 16 & 64.1 & 9.5 \\
\hline & & & & & 10 & 16 & 69.0 & 8.7 \\
\hline \multirow{3}{*}{$\begin{array}{c}\text { Dawson- } \\
\text { Hughes, B., } \\
\text { et al., } 1991 \text { [23] }\end{array}$} & & & & & & & & \\
\hline & Female & None & & 0 & 48 & 121 & 60.6 & 28.5 \\
\hline & & D3 & & 400 & 48 & 125 & 92.1 & 23.6 \\
\hline \multirow[t]{2}{*}{$\begin{array}{c}\text { Dawson- } \\
\text { Hughes, B., et } \\
\text { al., } 1995 \text { [24] }\end{array}$} & Female & $\begin{array}{c}\text { Not } \\
\text { specified }\end{array}$ & & 100 & 39 & 124 & 66.3 & 25.5 \\
\hline & & & & 700 & 39 & 123 & 100.1 & 24.5 \\
\hline \multirow[t]{2}{*}{$\begin{array}{l}\text { Diamond, T., } \\
\text { et al., } 2013 \text { [25] }\end{array}$} & Both & D3 & & 2000 & 12 & 11 & 75.3 & 15.9 \\
\hline & & & & 5000 & 12 & 15 & 114.4 & 22.2 \\
\hline \multirow[t]{2}{*}{$\begin{array}{l}\text { Gallagher, J.C., } \\
\text { et al., } 2014 \text { [26] }\end{array}$} & Both & D3 & $\begin{array}{l}\text { African } \\
\text { American } \\
\text { women }\end{array}$ & 2400 & 52 & 20 & 97.8 & 16.5 \\
\hline & & & $\begin{array}{c}\text { White } \\
\text { women }\end{array}$ & 2400 & 52 & 5 & 108.0 & 14.3 \\
\hline \multirow[t]{2}{*}{$\begin{array}{c}\text { Harris, S.S., } \\
\text { et al., } 2012 \text { [27] }\end{array}$} & Both & None & & 0 & 12 & 43 & 37.4 & 16.1 \\
\hline & & D3 & & 4000 & 12 & 46 & 81.1 & 27.9 \\
\hline \multirow[t]{4}{*}{$\begin{array}{l}\text { Holick, M.F., } \\
\text { et al., } 2008 \text { [28] }\end{array}$} & Both & None & & 0 & 11 & 16 & 47.0 & 19.8 \\
\hline & & D3 & & 1000 & 11 & 20 & 72.3 & 27.5 \\
\hline & & D2 & & 1000 & 11 & 18 & 67.0 & 24.0 \\
\hline & & D3+D2 & & 1000 & 11 & 14 & 71.0 & 19.3 \\
\hline \multirow[t]{3}{*}{$\begin{array}{l}\text { Jensen, C., et al., } \\
2002 \text { [29] }\end{array}$} & Female & $\begin{array}{c}\text { Not } \\
\text { specified }\end{array}$ & & 400 & 52 & 22 & 50.3 & 19.1 \\
\hline & & & & & 104 & 22 & 80.4 & 21.6 \\
\hline & & & & & 156 & 22 & 76.6 & 22.1 \\
\hline \multirow[t]{2}{*}{$\begin{array}{l}\text { Karkkainen, M.K., } \\
\text { et al., } 2010 \text { [30] }\end{array}$} & Female & D3 & & 0 & 156 & 287 & 55.9 & 21.8 \\
\hline & & & & 800 & 156 & 306 & 74.6 & 21.9 \\
\hline $\begin{array}{l}\text { Kilpinen-Loisa, P., } \\
\text { et al., } 2009 \text { [31] }\end{array}$ & Both & D3 & & 800 & 26 & 72 & 82.0 & 21.0 \\
\hline $\begin{array}{c}\text { Kyriakidou- } \\
\text { Himonas, M., } \\
\text { et al., } 1999 \text { [32] }\end{array}$ & Female & D3 & & 800 & 12 & 10 & 63.3 & 11.1 \\
\hline
\end{tabular}


Appendix. Cont.

\begin{tabular}{|c|c|c|c|c|c|c|c|c|}
\hline $\begin{array}{l}\text { Lagunova, Z., } \\
\text { et al., } 2013 \text { [33] }\end{array}$ & Both & D3 & & 2000 & 4 & 11 & 78.9 & 15.3 \\
\hline \multirow[t]{2}{*}{$\begin{array}{l}\text { Lappe, J.M., } \\
\text { et al., } 2007 \text { [34] }\end{array}$} & Female & None & & 0 & 52 & 446 & 71.1 & 19.8 \\
\hline & & D3 & & 1100 & 52 & 288 & 96.0 & 21.4 \\
\hline $\begin{array}{c}\text { Li-Ng, M., et al., } \\
2009 \text { [35] }\end{array}$ & Male & D3 & & 2000 & 12 & 78 & 88.5 & 23.2 \\
\hline \multirow[t]{12}{*}{$\begin{array}{l}\text { Logan, V.F., } \\
\text { et al., } 2013 \text { [36] }\end{array}$} & Both & None & & 0 & 4 & 13 & 71.0 & 15.3 \\
\hline & & & & & 8 & 13 & 61.0 & 15.3 \\
\hline & & & & & 13 & 13 & 44.0 & 15.3 \\
\hline & & & & & 25 & 13 & 37.0 & 17.9 \\
\hline & & D3 & & 1000 & 4 & 23 & 83.0 & 12.2 \\
\hline & & & & & 8 & 23 & 83.0 & 14.7 \\
\hline & & & & & 13 & 23 & 80.0 & 17.1 \\
\hline & & & & & 25 & 23 & 80.0 & 19.6 \\
\hline & & D2 & & 1000 & 4 & 25 & 70.0 & 12.9 \\
\hline & & & & & 8 & 25 & 66.0 & 12.9 \\
\hline & & & & & 13 & 25 & 62.0 & 14.7 \\
\hline & & & & & 25 & 25 & 56.0 & 11.0 \\
\hline \multirow[t]{6}{*}{$\begin{array}{l}\text { Molgaard, C., } \\
\text { et al., } 2010 \text { [37] }\end{array}$} & Female & None & & 0 & 26 & 73 & 47.0 & 20.0 \\
\hline & & & & & 52 & 73 & 39.7 & 17.7 \\
\hline & & D3 & & 200 & 26 & 74 & 54.5 & 12.0 \\
\hline & & & & & 52 & 74 & 52.9 & 16.3 \\
\hline & & & & 400 & 26 & 73 & 59.4 & 13.2 \\
\hline & & & & & 52 & 74 & 57.9 & 14.3 \\
\hline \multirow[t]{2}{*}{$\begin{array}{l}\text { Nelson, M.L., } \\
\text { et al., } 2009 \text { [38] }\end{array}$} & Female & None & & 0 & 52 & 31 & 72.7 & 27.8 \\
\hline & & D3 & & 800 & 52 & 31 & 97.4 & 31.3 \\
\hline \multirow[t]{4}{*}{$\begin{array}{l}\text { Oosterwerff, M.M., } \\
\text { et al., } 2014 \text { [39] }\end{array}$} & Both & None & & 0 & 8 & 53 & 24.0 & 16.0 \\
\hline & & & & & 16 & 53 & 23.0 & 15.0 \\
\hline & & D3 & & 1200 & 8 & 57 & 58.0 & 12.0 \\
\hline & & & & & 16 & 57 & 60.0 & 16.0 \\
\hline \multirow[t]{4}{*}{$\begin{array}{l}\text { Orwoll, E.S., } \\
\text { et al., } 1988 \text { [41] }\end{array}$} & Male & None & & 0 & 26 & 46 & 55.0 & 15.0 \\
\hline & & & & & 52 & 46 & 60.0 & 18.0 \\
\hline & & D3 & & 1000 & 26 & 46 & 75.0 & 18.0 \\
\hline & & & & & 52 & 46 & 85.0 & 20.0 \\
\hline \multirow[t]{3}{*}{$\begin{array}{l}\text { Orwoll, E.S., } \\
\text { et al., } 1989 \text { [40] }\end{array}$} & Both & None & & 0 & 104 & 14 & 45.0 & 22.5 \\
\hline & & D3 & & 1600 & 52 & 14 & 240.0 & 97.5 \\
\hline & & & & & 104 & 17 & 225.0 & 87.5 \\
\hline \multirow[t]{2}{*}{$\begin{array}{l}\text { Pignotti, G.A., } \\
\text { et al., } 2010 \text { [42] }\end{array}$} & Female & None & & 0 & 13 & 29 & 58.8 & 24.7 \\
\hline & & D3 & & 400 & 13 & 29 & 59.5 & 17.5 \\
\hline \multirow[t]{2}{*}{$\begin{array}{l}\text { Putman, M.S., } \\
\text { et al., } 2013 \text { [43] }\end{array}$} & Both & D3 & & 200 & 11 & 25 & 28.9 & 7.0 \\
\hline & & & & 1000 & 11 & 29 & 30.1 & 6.6 \\
\hline \multirow[t]{2}{*}{$\begin{array}{l}\text { Rajakumar, K., } \\
\text { et al., } 2008 \text { [44] }\end{array}$} & Both & D3 & Non-obese & 400 & 4 & 18 & 72.8 & 16.8 \\
\hline & & & Obese & 400 & 4 & 21 & 65.5 & 20.3 \\
\hline \multirow[t]{3}{*}{$\begin{array}{l}\text { Schaafsma, A., } \\
\text { et al., } 2000 \text { [45] }\end{array}$} & Female & D3 & & 400 & 13 & 46 & 108.0 & 25.0 \\
\hline & & & & & 26 & 46 & 111.0 & 23.0 \\
\hline & & & & & 52 & 46 & 121.0 & 27.0 \\
\hline
\end{tabular}


Appendix. Cont.

\begin{tabular}{|c|c|c|c|c|c|c|c|c|}
\hline \multirow{2}{*}{$\begin{array}{l}\text { Schnatz, P.F., } \\
\text { et al., } 2014 \text { [46] }\end{array}$} & Female & None & & 0 & 104 & 291 & 45.5 & 23.7 \\
\hline & & D3 & & 400 & 104 & 285 & 60.8 & 30.5 \\
\hline \multirow[t]{4}{*}{$\begin{array}{c}\text { Schou, A.J., et al., } \\
2003 \text { [47] }\end{array}$} & Both & None & $\begin{array}{l}\text { Placebo } \\
\text { then } \\
\text { suppleme } \\
\text { ntation }\end{array}$ & 0 & 4 & 10 & 33.7 & 10.4 \\
\hline & & & $\begin{array}{l}\text { Suppleme } \\
\text { ntation } \\
\text { then } \\
\text { placebo } \\
\text { Placebo }\end{array}$ & 0 & 4 & 10 & 32.3 & 13.0 \\
\hline & & D3 & $\begin{array}{l}\text { Placebo } \\
\text { then } \\
\text { suppleme } \\
\text { ntation }\end{array}$ & 600 & 4 & 10 & 50.2 & 14.2 \\
\hline & & & $\begin{array}{l}\text { Suppleme } \\
\text { ntation } \\
\text { then } \\
\text { placebo }\end{array}$ & 600 & 4 & 10 & 43.4 & 9.2 \\
\hline \multirow[t]{8}{*}{$\begin{array}{l}\text { Smith, S.M., } \\
\text { et al., } 2009 \text { [48] }\end{array}$} & Both & None & & 0 & 18 & 18 & 38.0 & 17.0 \\
\hline & & & & & 25 & 18 & 34.0 & 12.0 \\
\hline & & D3 & & 400 & 18 & 19 & 55.0 & 19.0 \\
\hline & & & & & 25 & 19 & 57.0 & 15.0 \\
\hline & & & & 1000 & 18 & 18 & 63.0 & 20.0 \\
\hline & & & & & 25 & 18 & 63.0 & 25.0 \\
\hline & & & & 2000 & 18 & 7 & 71.0 & 20.0 \\
\hline & & & & & 25 & 7 & 71.0 & 23.0 \\
\hline \multirow[t]{4}{*}{$\begin{array}{l}\text { Van Der Klis, F.R., } \\
\text { et al., } 1996 \text { [49] }\end{array}$} & Female & None & & 0 & 5 & 41 & 58.5 & 10.7 \\
\hline & & D3 & & 400 & 5 & 19 & 87.9 & 28.1 \\
\hline & & & & 800 & 5 & 19 & 87.9 & 28.1 \\
\hline & & & & & & 19 & 102.6 & 28.8 \\
\hline \multirow[t]{2}{*}{$\begin{array}{l}\text { Vieth, R., et al., } \\
2001 \text { [50] }\end{array}$} & Both & D3 & & 1000 & 12 & 33 & 68.7 & 16.9 \\
\hline & & & & 4000 & 12 & 28 & 96.4 & 14.6 \\
\hline \multirow[t]{2}{*}{$\begin{array}{l}\text { Wamberg, L., } \\
\text { et al., } 2013 \text { [51] }\end{array}$} & Both & None & & 0 & 26 & 26 & 46.8 & 21.2 \\
\hline & & D3 & & 7000 & 26 & 26 & 110.0 & 17.3 \\
\hline \multirow[t]{2}{*}{$\begin{array}{c}\text { Zwart, S.R., et } \\
\text { al., } 2011 \text { [52] }\end{array}$} & Both & $\begin{array}{c}\text { Not } \\
\text { specified }\end{array}$ & & 2000 & 13 & 15 & 73.0 & 17.0 \\
\hline & & & & & 26 & 15 & 79.0 & 16.0 \\
\hline
\end{tabular}

Footnote: SD: Standard Deviation: Reported SD ranged from 6.6 to 97.5, had a mean value of 19.9 and a median value of $17.8 \mathrm{nmol} / \mathrm{L}$.

\section{References}

1. Institute of Medicine; Food and Nutrition Board. Dietary Reference Intakes for Calcium and Vitamin D; National Academies Press: Washington, DC, USA, 2011.

2. Maxmen, A. Nutrition advice: The vitamin D-lemma. Nature 2011, 475, 23-25.

3. Holick, M.F.; Binkley, N.C.; Bischoff-Ferrari, H.A.; Gordon, C.M.; Hanley, D.A.; Heaney, R.P.; Murad, M.H.; Weaver, C.M.; Endocrine, S. Evaluation, treatment, and prevention of vitamin D deficiency: An Endocrine Society clinical practice guideline. J. Clin. Endocrinol. Metab. 2011, 96, 1911-1930.

4. Ekwaru, J.P.; Zwicker, J.D.; Holick, M.F.; Giovannucci, E.; Veugelers, P.J. The importance of body weight for the dose response relationship of oral vitamin D supplementation and serum 25-hydroxyvitamin D in healthy volunteers. PLOS ONE 2014, 9, e111265.

5. Zittermann, A.; Ernst, J.B.; Gummert, J.F.; Borgermann, J. Vitamin D supplementation, body weight and human serum 25-hydroxyvitamin D response: A systematic review. Eur. J. Nutr. 2014, 53, 367-374. 
6. Van Groningen, L.; Opdenoordt, S.; van Sorge, A.; Telting, D.; Giesen, A.; de Boer, H. Cholecalciferol loading dose guideline for vitamin D-deficient adults. Eur. J. Endocrinol. Eur. Fed. Endocr. Soc. 2010, 162, 805-811.

7. Heaney, R.P.; Davies, K.M.; Chen, T.C.; Holick, M.F.; Barger-Lux, M.J. Human serum 25-hydroxycholecalciferol response to extended oral dosing with cholecalciferol. Am. J. Clin. Nutr. 2003, 77, 204-210.

8. Janz, T.; Pearson, C. Vitamin D Blood Levels of Canadians. In Health at a Glance, Statistics Canada (Catalogue No. 82-624-X); Statistics Canada: Ottawa, ON, Canada, 2013.

9. Greene-Finestone, L.; Berger, C.; de Groh, M.; Hanley, D.; Hidiroglou, N.; Sarafin, K.; Poliquin, S.; Krieger, J.; Richards, J.; Goltzman, D. 25-Hydroxyvitamin D in Canadian adults: Biological, environmental, and behavioral correlates. Osteoporos. Int. 2011, 22, 1389-1399.

10. Veugelers, P.J.; Ekwaru, J.P. A Statistical Error in the Estimation of the Recommended Dietary Allowance for Vitamin D. Nutrients 2014, 6, 4472-4475, doi:10.3390/nu6104472.

11. Heaney, R.; Garland, C.; Baggerly, C.; French, C.; Gorham, E. Letter to Veugelers, P.J. and Ekwaru, J.P., A Statistical Error in the Estimation of the Recommended Dietary Allowance for Vitamin D. Nutrients 2015, 7, 1688-1690.

12. Garland, C.F.; French, C.B.; Baggerly, L.L.; Heaney, R.P. Vitamin D supplement doses and serum 25-hydroxyvitamin D in the range associated with cancer prevention. Anticancer Res. 2011, 31, 607-611.

13. Pham, T.M.; Ekwaru, J.P.; Setayeshgar, S.; Veugelers, P.J. The Effect of Changing Serum 25-Hydroxyvitamin D Concentrations on Metabolic Syndrome: A Longitudinal Analysis of Participants of a Preventive Health Program. Nutrients 2015, 7, 7271-7284.

14. Ekwaru, J.P.; Ohinmaa, A.; Veugelers, P.J. The effectiveness of a preventive health program and vitamin D status in improving health-related quality of life of older Canadians. Qual. Life Res. 2015, doi:10.1007/s11136-015-1103-7.

15. Koenker, R.; Bassett, G., Jr. Regression quantiles. Econom. J. Econom. Soc. 1978, 46, 33-50.

16. Luxwolda, M.F.; Kuipers, R.S.; Kema, I.P.; Dijck-Brouwer, D.A.; Muskiet, F.A. Traditionally living populations in East Africa have a mean serum 25-hydroxyvitamin D concentration of $115 \mathrm{nmol} / \mathrm{l}$. Br. J. Nutr. 2012, 108, 1557-1561.

17. Ala-Houhala, M.; Koskinen, T.; Koskinen, M.; Visakorpi, J.K. Double blind study on the need for vitamin D supplementation in prepubertal children. Acta Paediatr. Scand. 1988, 77, 89-93.

18. Aloia, J.; Bojadzievski, T.; Yusupov, E.; Shahzad, G.; Pollack, S.; Mikhail, M.; Yeh, J. The relative influence of calcium intake and vitamin $\mathrm{D}$ status on serum parathyroid hormone and bone turnover biomarkers in a double-blind, placebo-controlled parallel group, longitudinal factorial design. J. Clin. Endocrinol. Metab. 2010, 95, 3216-3224.

19. Aloia, J.F.; Talwar, S.A.; Pollack, S.; Yeh, J. A randomized controlled trial of vitamin D3 supplementation in African American women. Arch. Intern. Med. 2005, 165, 1618-1623.

20. Biancuzzo, R.M.; Young, A.; Bibuld, D.; Cai, M.H.; Winter, M.R.; Klein, E.K.; Ameri, A.; Reitz, R.; Salameh, W.; Chen, T.C.; et al. Fortification of orange juice with vitamin $\mathrm{D}(2)$ or vitamin $\mathrm{D}(3)$ is as effective as an oral supplement in maintaining vitamin D status in adults. Am. J. Clin. Nutr. 2010, 91, 1621-1626.

21. Bolton-Smith, C.; McMurdo, M.E.; Paterson, C.R.; Mole, P.A.; Harvey, J.M.; Fenton, S.T.; Prynne, C.J.; Mishra, G.D.; Shearer, M.J. Two-year randomized controlled trial of vitamin K1 (phylloquinone) and vitamin D3 plus calcium on the bone health of older women. J. Bone Miner. Res. 2007, 22, 509-519.

22. Cashman, K.D.; Seamans, K.M.; Lucey, A.J.; Stocklin, E.; Weber, P.; Kiely, M.; Hill, T.R. Relative effectiveness of oral 25-hydroxyvitamin D3 and vitamin D3 in raising wintertime serum 25-hydroxyvitamin D in older adults. Am. J. Clin. Nutr. 2012, 95, 1350-1356.

23. Dawson-Hughes, B.; Dallal, G.E.; Krall, E.A.; Harris, S.; Sokoll, L.J.; Falconer, G. Effect of vitamin D supplementation on wintertime and overall bone loss in healthy postmenopausal women. Ann. Intern. Med. 1991, 115, 505-512.

24. Dawson-Hughes, B.; Harris, S.S.; Krall, E.A.; Dallal, G.E.; Falconer, G.; Green, C.L. Rates of bone loss in postmenopausal women randomly assigned to one of two dosages of vitamin D. Am. J. Clin. Nutr. 1995, 61, 1140-1145.

25. Diamond, T.; Wong, Y.K.; Golombick, T. Effect of oral cholecalciferol 2000 versus 5000 IU on serum vitamin D, PTH, bone and muscle strength in patients with vitamin D deficiency. Osteoporos. Int. 2013, 24, 1101-1105.

26. Gallagher, J.C.; Jindal, P.S.; Smith, L.M. Vitamin D supplementation in young White and African American women. J. Bone Miner. Res. 2014, 29, 173-181. 
27. Harris, S.S.; Pittas, A.G.; Palermo, N.J. A randomized, placebo-controlled trial of vitamin D supplementation to improve glycaemia in overweight and obese African Americans. Diabetes Obes. Metab. 2012, 14, 789-794.

28. Holick, M.F.; Biancuzzo, R.M.; Chen, T.C.; Klein, E.K.; Young, A.; Bibuld, D.; Reitz, R.; Salameh, W.; Ameri, A.; Tannenbaum, A.D. Vitamin D2 is as effective as vitamin D3 in maintaining circulating concentrations of 25-hydroxyvitamin D. J. Clin. Endocrinol. Metab. 2008, 93, 677-681.

29. Jensen, C.; Holloway, L.; Block, G.; Spiller, G.; Gildengorin, G.; Gunderson, E.; Butterfield, G.; Marcus, R. Long-term effects of nutrient intervention on markers of bone remodeling and calciotropic hormones in late-postmenopausal women. Am. J. Clin. Nutr. 2002, 75, 1114-1120.

30. Karkkainen, M.K.; Tuppurainen, M.; Salovaara, K.; Sandini, L.; Rikkonen, T.; Sirola, J.; Honkanen, R.; Arokoski, J.; Alhava, E.; Kroger, H. Does daily vitamin D 800 IU and calcium 1000 mg supplementation decrease the risk of falling in ambulatory women aged 65-71 years? A 3-year randomized population-based trial (OSTPRE-FPS). Maturitas 2010, 65, 359-365.

31. Kilpinen-Loisa, P.; Arvio, M.; Ilvesmaki, V.; Makitie, O. Vitamin D status and optimal supplementation in institutionalized adults with intellectual disability. J. Intellect. Disabil. Res. JIDR 2009, 53, 1014-1023.

32. Kyriakidou-Himonas, M.; Aloia, J.F.; Yeh, J.K. Vitamin D supplementation in postmenopausal black women. J. Clin. Endocrinol. Metab. 1999, 84, 3988-3990.

33. Lagunova, Z.; Porojnicu, A.C.; Aksnes, L.; Holick, M.F.; Iani, V.; Bruland, O.S.; Moan, J. Effect of vitamin D supplementation and ultraviolet B exposure on serum 25-hydroxyvitamin D concentrations in healthy volunteers: A randomized, crossover clinical trial. Br. J. Dermatol. 2013, 169, 434-440.

34. Lappe, J.M.; Travers-Gustafson, D.; Davies, K.M.; Recker, R.R.; Heaney, R.P. Vitamin D and calcium supplementation reduces cancer risk: Results of a randomized trial. Am. J. Clin. Nutr. 2007, 85, 1586-1591.

35. Li-Ng, M.; Aloia, J.F.; Pollack, S.; Cunha, B.A.; Mikhail, M.; Yeh, J.; Berbari, N. A randomized controlled trial of vitamin D3 supplementation for the prevention of symptomatic upper respiratory tract infections. Epidemiol. Infect. 2009, 137, 1396-1404.

36. Logan, V.F.; Gray, A.R.; Peddie, M.C.; Harper, M.J.; Houghton, L.A. Long-term vitamin D3 supplementation is more effective than vitamin D2 in maintaining serum 25-hydroxyvitamin D status over the winter months. Br. J. Nutr. 2013, 109, 1082-1088.

37. Molgaard, C.; Larnkjaer, A.; Cashman, K.D.; Lamberg-Allardt, C.; Jakobsen, J.; Michaelsen, K.F. Does vitamin D supplementation of healthy Danish Caucasian girls affect bone turnover and bone mineralization? Bone 2010, 46, 432-439.

38. Nelson, M.L.; Blum, J.M.; Hollis, B.W.; Rosen, C.; Sullivan, S.S. Supplements of 20 microg/d cholecalciferol optimized serum 25 -hydroxyvitamin D concentrations in $80 \%$ of premenopausal women in winter. J. Nutr. 2009, 139, 540-546.

39. Oosterwerff, M.M.; Eekhoff, E.M.; van Schoor, N.M.; Boeke, A.J.; Nanayakkara, P.; Meijnen, R.; Knol, D.L.; Kramer, M.H.; Lips, P. Effect of moderate-dose vitamin D supplementation on insulin sensitivity in vitamin D-deficient non-Western immigrants in the Netherlands: A randomized placebo-controlled trial. Am. J. Clin. Nutr. 2014, 100, 152-160.

40. Orwoll, E.S.; McClung, M.R.; Oviatt, S.K.; Recker, R.R.; Weigel, R.M. Histomorphometric effects of calcium or calcium plus 25-hydroxyvitamin D3 therapy in senile osteoporosis. J. Bone Miner. Res. 1989, 4, 81-88.

41. Orwoll, E.S.; Weigel, R.M.; Oviatt, S.K.; McClung, M.R.; Deftos, L.J. Calcium and cholecalciferol: Effects of small supplements in normal men. Am. J. Clin. Nutr. 1988, 48, 127-130.

42. Pignotti, G.A.; Genaro, P.S.; Pinheiro, M.M.; Szejnfeld, V.L.; Martini, L.A. Is a lower dose of vitamin D supplementation enough to increase 25(OH)D status in a sunny country? Eur. J. Nutr. 2010, 49, 277-283.

43. Putman, M.S.; Pitts, S.A.; Milliren, C.E.; Feldman, H.A.; Reinold, K.; Gordon, C.M. A randomized clinical trial of vitamin D supplementation in healthy adolescents. J. Adolesc. Health Off. Publ. Soc. Adolesc. Med. 2013, $52,592-598$.

44. Rajakumar, K.; Fernstrom, J.D.; Holick, M.F.; Janosky, J.E.; Greenspan, S.L. Vitamin D status and response to Vitamin D(3) in obese vs. non-obese African American children. Obesity (Silver Spring) 2008, 16, 90-95.

45. Schaafsma, A.; Muskiet, F.A.; Storm, H.; Hofstede, G.J.; Pakan, I.; van der Veer, E. Vitamin D(3) and vitamin $\mathrm{K}(1)$ supplementation of Dutch postmenopausal women with normal and low bone mineral densities: Effects on serum 25-hydroxyvitamin D and carboxylated osteocalcin. Eur. J. Clin. Nutr. 2000, 54, 626-631.

46. Schnatz, P.F.; Jiang, X.; Vila-Wright, S.; Aragaki, A.K.; Nudy, M.; O’Sullivan, D.M.; Jackson, R.; LeBlanc, E.; Robinson, J.G.; Shikany, J.M.; et al. Calcium/vitamin D supplementation, serum 25-hydroxyvitamin D 
concentrations, and cholesterol profiles in the Women's Health Initiative calcium/vitamin D randomized trial. Menopause 2014, 21, 823-833.

47. Schou, A.J.; Heuck, C.; Wolthers, O.D. A randomized, controlled lower leg growth study of vitamin D supplementation to healthy children during the winter season. Ann. Hum. Biol. 2003, 30, 214-219.

48. Smith, S.M.; Gardner, K.K.; Locke, J.; Zwart, S.R. Vitamin D supplementation during Antarctic winter. Am. J. Clin. Nutr. 2009, 89, 1092-1098.

49. Van Der Klis, F.R.; Jonxis, J.H.; van Doormaal, J.J.; Sikkens, P.; Saleh, A.E.; Muskiet, F.A. Changes in vitamin-D metabolites and parathyroid hormone in plasma following cholecalciferol administration to preand postmenopausal women in the Netherlands in early spring and to postmenopausal women in Curacao. Br. J. Nutr. 1996, 75, 637-646.

50. Vieth, R.; Chan, P.C.; MacFarlane, G.D. Efficacy and safety of vitamin D3 intake exceeding the lowest observed adverse effect level. Am. J. Clin. Nutr. 2001, 73, 288-294.

51. Wamberg, L.; Pedersen, S.B.; Richelsen, B.; Rejnmark, L. The effect of high-dose vitamin D supplementation on calciotropic hormones and bone mineral density in obese subjects with low levels of circulating 25-hydroxyvitamin d: Results from a randomized controlled study. Calcif. Tissue Int. 2013, 93, 69-77.

52. Zwart, S.R.; Mehta, S.K.; Ploutz-Snyder, R.; Bourbeau, Y.; Locke, J.P.; Pierson, D.L.; Smith, S.M. Response to vitamin D supplementation during Antarctic winter is related to BMI, and supplementation can mitigate Epstein-Barr Virus Reactivation. J. Nutr. 2011, 141, 692-697.

53. Statistics Canada. Vitamin D Levels of Canadians. 2012 to 2013. Available online: http://www.statcan.gc.ca/pub/82-625-x/2014001/article/14125-eng.htm (accessed on 11 August 2015).

54. Holick, M. Vitamin D deficiency. N. Engl. J. Med. 2007, 357, 266-281.

55. Thacher, T.D.; Clarke, B.L. Vitamin D insufficiency. Mayo Clin. Proc. 2011, 86, 50-60.

56. Hagenau, T.; Vest, R.; Gissel, T.N.; Poulsen, C.S.; Erlandsen, M.; Mosekilde, L.; Vestergaard, P. Global vitamin $\mathrm{D}$ levels in relation to age, gender, skin pigmentation and latitude: An ecologic meta-regression analysis. Osteoporos. Int. 2009, 20, 133-140.

57. Hilger, J.; Friedel, A.; Herr, R.; Rausch, T.; Roos, F.; Wahl, D.A.; Pierroz, D.D.; Weber, P.; Hoffmann, K. A systematic review of vitamin D status in populations worldwide. Br. J. Nutr. 2014, 111, 23-45.

58. Wahl, D.A.; Cooper, C.; Ebeling, P.R.; Eggersdorfer, M.; Hilger, J.; Hoffmann, K.; Josse, R.; Kanis, J.A.; Mithal, A.; Pierroz, D.D.; et al. A global representation of vitamin D status in healthy populations. Arch. Osteoporos. 2012, 7, 155-172.

59. Vatanparast, H.; Calvo, M.S.; Green, T.J.; Whiting, S.J. Despite mandatory fortification of staple foods, vitamin D intakes of Canadian children and adults are inadequate. J. Steroid Biochem. Mol. Biol. 2010, 121, 301-303.

60. Munasinghe, L.L.; Willows, N.; Yuan, Y.; Veugelers, P.J. Dietary reference intakes for vitamin D based on the revised 2010 dietary guidelines are not being met by children in Alberta, Canada. Nutr. Res. 2015, 35, 956-964.

61. Crowe, F.L.; Steur, M.; Allen, N.E.; Appleby, P.N.; Travis, R.C.; Key, T.J. Plasma concentrations of 25-hydroxyvitamin D in meat eaters, fish eaters, vegetarians and vegans: Results from the EPIC-Oxford study. Public Health Nutr. 2011, 14, 340-346.

62. Dawson-Hughes, B.; Harris, S.S.; Lichtenstein, A.H.; Dolnikowski, G.; Palermo, N.J.; Rasmussen, H. Dietary fat increases vitamin D-3 absorption. J. Acad. Nutr. Diet. 2015, 115, 225-230.

63. Mulligan, G.B.; Licata, A. Taking vitamin D with the largest meal improves absorption and results in higher serum levels of 25-hydroxyvitamin D. J. Bone Miner. Res. 2010, 25, 928-930.

64. Raimundo, F.V.; Faulhaber, G.A.; Menegatti, P.K.; Marques Lda, S.; Furlanetto, T.W. Effect of High- versus Low-Fat Meal on Serum 25-Hydroxyvitamin D Levels after a Single Oral Dose of Vitamin D: A Single-Blind, Parallel, Randomized Trial. Int. J. Endocrinol. 2011, 2011, 809069.

65. Ahn, J.; Yu, K.; Stolzenberg-Solomon, R.; Simon, K.C.; McCullough, M.L.; Gallicchio, L.; Jacobs, E.J.; Ascherio, A.; Helzlsouer, K.; Jacobs, K.B.; et al. Genome-wide association study of circulating vitamin D levels. Hum. Mol. Genet. 2010, 19, 2739-2745.

66. Barry, E.L.; Rees, J.R.; Peacock, J.L.; Mott, L.A.; Amos, C.I.; Bostick, R.M.; Figueiredo, J.C.; Ahnen, D.J.; Bresalier, R.S.; Burke, C.A.; et al. Genetic variants in CYP2R1, CYP24A1, and VDR modify the efficacy of vitamin D3 supplementation for increasing serum 25-hydroxyvitamin D levels in a randomized controlled trial. J. Clin. Endocrinol. Metab. 2014, 99, E2133-2137. 
67. Buijsse, B.; Boeing, H.; Hirche, F.; Weikert, C.; Schulze, M.B.; Gottschald, M.; Kuhn, T.; Katzke, V.A.; Teucher, B.; Dierkes, J.; et al. Plasma 25-hydroxyvitamin D and its genetic determinants in relation to incident type 2 diabetes: A prospective case-cohort study. Eur. J. Epidemiol. 2013, 28, 743-752.

68. Didriksen, A.; Grimnes, G.; Hutchinson, M.S.; Kjaergaard, M.; Svartberg, J.; Joakimsen, R.M.; Jorde, R. The serum 25-hydroxyvitamin D response to vitamin D supplementation is related to genetic factors, BMI, and baseline levels. Eur. J. Endocrinol. Eur. Fed. Endocr.Soc. 2013, 169, 559-567.

69. Engelman, C.D.; Meyers, K.J.; Iyengar, S.K.; Liu, Z.; Karki, C.K.; Igo, R.P., Jr.; Truitt, B.; Robinson, J.; Sarto, G.E.; Wallace, R.; et al. Vitamin D intake and season modify the effects of the GC and CYP2R1 genes on 25-hydroxyvitamin D concentrations. J. Nutr. 2013, 143, 17-26.

70. Hansen, J.G.; Tang, W.; Hootman, K.C.; Brannon, P.M.; Houston, D.K.; Kritchevsky, S.B.; Harris, T.B.; Garcia, M.; Lohman, K.; Liu, Y.; et al. Genetic and environmental factors are associated with serum 25-hydroxyvitamin D concentrations in older African Americans. J. Nutr. 2015, 145, 799-805.

71. Levin, G.P.; Robinson-Cohen, C.; de Boer, I.H.; Houston, D.K.; Lohman, K.; Liu, Y.; Kritchevsky, S.B.; Cauley, J.A.; Tanaka, T.; Ferrucci, L.; et al. Genetic variants and associations of 25-hydroxyvitamin D concentrations with major clinical outcomes. JAMA 2012, 308, 1898-1905.

72. Sollid, S.T.; Hutchinson, M.Y.; Fuskevag, O.M.; Joakimsen, R.M.; Jorde, R. Large Individual Differences in Serum 25-Hydroxyvitamin D Response to Vitamin D Supplementation: Effects of Genetic Factors, Body Mass Index, and Baseline Concentration. Results from a Randomized Controlled Trial. Horm. Metab. Res. 2015, doi:10.1055/s-0034-1398617.

73. Wang, T.J.; Zhang, F.; Richards, J.B.; Kestenbaum, B.; van Meurs, J.B.; Berry, D.; Kiel, D.P.; Streeten, E.A.; Ohlsson, C.; Koller, D.L.; et al. Common genetic determinants of vitamin D insufficiency: A genome-wide association study. Lancet 2010, 376, 180-188.

74. Institute of Medicine. How the RDA for Vitamin D Was Determined. Available Online: http://iom.nationalacademies.org/Global/News\%20Announcements/How-the-RDA-for-Vitamin-D-WasDetermined (accessed on 8 August 2014).

75. American Geriatrics Society Workgroup on Vitamin, D.S.f.O.A. Recommendations abstracted from the American Geriatrics Society Consensus Statement on vitamin D for Prevention of Falls and Their Consequences. J. Am. Geriatr. Soc. 2014, 62, 147-152.

76. Heaney, R.P. The Vitamin D requirement in health and disease. J. Steroid Biochem. Mol. Biol. 2005, 97, 13-19.

77. Holick, M.F.; Binkley, N.C.; Bischoff-Ferrari, H.A.; Gordon, C.M.; Hanley, D.A.; Heaney, R.P.; Murad, M.H.; Weaver, C.M. Guidelines for preventing and treating vitamin D deficiency and insufficiency revisited. J. Clin. Endocrinol. Metab. 2012, 97, 1153-1158.

78. Trivedi, D.P.; Doll, R.; Khaw, K.T. Effect of four monthly oral vitamin D3 (cholecalciferol) supplementation on fractures and mortality in men and women living in the community: Randomised double blind controlled trial. BMJ 2003, 326, 469-469.

79. Bischoff-Ferrari, H.A.; Willett, W.C.; Wong, J.B.; Giovannucci, E.; Dietrich, T.; Dawson-Hughes, B. Fracture prevention with vitamin D supplementation: A meta-analysis of randomized controlled trials. JAMA 2005, 293, 2257-2264.

80. Von Hurst, P.R.; Stonehouse, W.; Coad, J. Vitamin D supplementation reduces insulin resistance in South Asian women living in New Zealand who are insulin resistant and vitamin D deficient-A randomised, placebo-controlled trial. Br. J. Nutr. 2010, 103, 549-555.

81. Wang, L.; Song, Y.; Manson, J.E.; Pilz, S.; Marz, W.; Michaelsson, K.; Lundqvist, A.; Jassal, S.K.; Barrett-Connor, E.; Zhang, C.; et al. Circulating 25-hydroxy-vitamin D and risk of cardiovascular disease: A meta-analysis of prospective studies. Circ. Cardiovasc. Qual. Outcomes 2012, 5, 819-829.

82. Giovannucci, E.; Liu, Y.; Hollis, B.W.; Rimm, E.B. 25-hydroxyvitamin D and risk of myocardial infarction in men: A prospective study. Arch. Intern. Med. 2008, 168, 1174-1180.

83. Garland, C.F.; Garland, F.C.; Gorham, E.D.; Lipkin, M.; Newmark, H.; Mohr, S.B.; Holick, M.F. The role of vitamin D in cancer prevention. Am. J. Public Health 2006, 96, 252-261.

84. Garland, C.F.; Gorham, E.D.; Mohr, S.B.; Grant, W.B.; Giovannucci, E.L.; Lipkin, M.; Newmark, H.; Holick, M.F.; Garland, F.C. Vitamin D and prevention of breast cancer: Pooled analysis. J. Steroid Biochem. Mol. Biol. 2007, 103, 708-711.

85. Bolland, M.J.; Grey, A.; Gamble, G.D.; Reid, I.R. Calcium and vitamin D supplements and health outcomes: A reanalysis of the Women's Health Initiative (WHI) limited-access data set. Am. J. Clin.Nutr. 2011, 94, 1144-1149. 
86. Lowe, L.C.; Guy, M.; Mansi, J.L.; Peckitt, C.; Bliss, J.; Wilson, R.G.; Colston, K.W. Plasma 25-hydroxy vitamin $\mathrm{D}$ concentrations, vitamin $\mathrm{D}$ receptor genotype and breast cancer risk in a UK Caucasian population. Eur. J. Cancer 2005, 41, 1164-1169.

87. Garland, C.F.; Comstock, G.W.; Garland, F.C.; Helsing, K.J.; Shaw, E.K.; Gorham, E.D. Serum 25-hydroxyvitamin D and colon cancer: Eight-year prospective study. Lancet 1989, 2, 1176-1178.

88. Grant, W.B. Solar ultraviolet irradiance and cancer incidence and mortality. Adv. Exp. Med. Biol. 2014, 810, 52-68.

89. Munger, K.L.; Levin, L.I.; Hollis, B.W.; Howard, N.S.; Ascherio, A. Serum 25-hydroxyvitamin D levels and risk of multiple sclerosis. JAMA 2006, 296, 2832-2838.

90. Ginde, A.A.; Mansbach, J.M.; Camargo, C.A. Association between serum 25-hydroxyvitamin D level and upper respiratory tract infection in the Third National Health and Nutrition Examination Survey. Arch. Intern. Med. 2009, 169, 384-390.

91. Laaksi, I.; Ruohola, J.P.; Tuohimaa, P.; Auvinen, A.; Haataja, R.; Pihlajam\{ł"a\}ki, H.; Ylikomi, T. An association of serum vitamin $\mathrm{D}$ concentrations $<40 \mathrm{nmol} / \mathrm{L}$ with acute respiratory tract infection in young Finnish men. Am. J. Clin. Nutr. 2007, 86, 714-717.

92. Urashima, M.; Segawa, T.; Okazaki, M.; Kurihara, M.; Wada, Y.; Ida, H. Randomized trial of vitamin D supplementation to prevent seasonal influenza A in schoolchildren. Am. J. Clin. Nutr. 2010, 91, 1255-1260.

93. Manson, J.E.; Bassuk, S.S. Vitamin D research and clinical practice: At a crossroads. JAMA 2015, 313, 1311-1312.

94. Dror, Y.; Giveon, S.M.; Hoshen, M.; Feldhamer, I.; Balicer, R.D.; Feldman, B.S. Vitamin D levels for preventing acute coronary syndrome and mortality: Evidence of a nonlinear association. J. Clin. Endocrinol. Metab. 2013, 98, 2160-2167.

95. Durup, D.; Jorgensen, H.L.; Christensen, J.; Tjonneland, A.; Olsen, A.; Halkjaer, J.; Lind, B.; Heegaard, A.M.; Schwarz, P. A Reverse J-Shaped Association Between Serum 25-Hydroxyvitamin D and Cardiovascular Disease Mortality: The CopD Study. J. Clin. Endocrinol. Metab. 2015, 100, 2339-2346.

96. Xu, Y.; Shao, X.; Yao, Y.; Xu, L.; Chang, L.; Jiang, Z.; Lin, Z. Positive association between circulating 25-hydroxyvitamin D levels and prostate cancer risk: New findings from an updated meta-analysis. J. Cancer Res. Clin. Oncol. 2014, 140, 1465-1477.

97. Zittermann, A.; Kuhn, J.; Dreier, J.; Knabbe, C.; Gummert, J.F.; Borgermann, J. Vitamin D status and the risk of major adverse cardiac and cerebrovascular events in cardiac surgery. Eur. Heart J. 2013, 34, 1358-1364.

98. Zittermann, A.; Kuhn, J.; Ernst, J.B.; Becker, T.; Dreier, J.; Knabbe, C.; Gummert, J.F.; Borgermann, J. 25-hydroxyvitamin D, 1,25-dihydroxyvitamin D and postoperative outcome in cardiac surgery. J. Clin. Endocrinol. Metab. 2015, 100, 72-80.

99. Dudenkov, D.V.; Yawn, B.P.; Oberhelman, S.S.; Fischer, P.R.; Singh, R.J.; Cha, S.S.; Maxson, J.A.; Quigg, S.M.; Thacher, T.D. Changing Incidence of Serum 25-Hydroxyvitamin D Values Above 50 ng/mL: A 10-Year Population-Based Study. Mayo Clin. Proc. 2015, 90, 577-586.

100. Bischoff-Ferrari, H.A.; Shao, A.; Dawson-Hughes, B.; Hathcock, J.; Giovannucci, E.; Willett, W.C. Benefit-risk assessment of vitamin D supplementation. Osteoporos. Int. 2010, 21, 1121-1132.

101. Hathcock, J.N.; Shao, A.; Vieth, R.; Heaney, R. Risk assessment for vitamin D. Am. J. Clin. Nutr. 2007, 85, 6-18.

102. Holick, M.F. Vitamin D Is Not as Toxic as Was Once Thought: A Historical and an Up-to-Date Perspective. Mayo Clin. Proc. 2015, 90, 561-564.

103. Spedding, S.; Vanlint, S.; Morris, H.; Scragg, R. Does vitamin D sufficiency equate to a single serum 25-hydroxyvitamin D level or are different levels required for non-skeletal diseases? Nutrients 2013, 5, 5127-5139.

(C) 2015 by the authors; licensee MDPI, Basel, Switzerland. This article is an open access article distributed under the terms and conditions of the Creative Commons by Attribution (CC-BY) license (http://creativecommons.org/licenses/by/4.0/). 